\title{
O tempora! O mores! Generační a věkové souvislosti morálky ve stárnoucí společnosti ${ }^{1}$
}

\author{
O tempora! O mores! Generational and Age Context \\ of Morality in an Ageing Society
}

Lucie Vidovićová

\begin{abstract}
In this paper we look at European Value Study questions on justification of different types of behaviour in inter- and intra- generational, and cultural perspective. This justification is generally increasing; however the differences are not so big that we could talk about revolution in the morality of Czech society. Older people, often considered as the bearers of traditional values, tend to be more conservative than younger age groups, but they too show general tendencies towards liberalism in both dimensions under study - civic morality and permissiveness towards issues such as divorce, in-vitro fertilization or homosexuality. Except for age these attitudes are influenced mainly by sex, education and religiosity of the respondent. Intra- and inter-generational effects tend to support each other, but not unanimously in all dimensions, and they are strongly culture-specific. We wrap up our discussions with theoretical reflexion of the "value-change-due-to-populational-ageing" discourse in our society.
\end{abstract}

KEY WORDS cohort effects, European Value Study, morality, life cycle effects, populational ageing

\section{Úvod do problému}

Rabušic a Hamanová (2009) parafrázujíce amerického psychologa Allporta uvádí, že „,budoucnost můžeme nejlépe odhadovat tím, že věnujeme pozornost hodnotám, které lidé zastávají, a že si všímáme proměn, které v nich nastávají... [ČClověka (totiž) poznáme nejlépe tehdy, pokud víme, jaký druh budoucnosti vyvolá - a jeho tvarování budoucnosti závisí především na jeho personálních hodnotách“ (Rabušic a Hamanová 2009: 13). V tomto příspěvku se proto odrážíme od veřejně artikulované obavy o vývoj budoucích hodnot české společnosti a na základě dat Evropského výzkumu hodnot (EVS) se pokusíme ukázat, jaké morální,

Sociální studia. Fakulta sociálních studií Masarykovy univerzity, 4/2010. S. 11-36. ISSN 1214-813X.

1 Tento článek byl podpořen z prostředků Institutu pro výzkum reprodukce a integrace společnosti (MSM 0021622408). Data EVS jsou k dispozici díky grantovému projektu GAČR 403/08/0999. Téma generační morálky zjištované na základě dat EVS bylo již v roce 1995 publikováno jako studentská práce v rámci soutěže I. A. Bláhy, jejím zadavatelem byl prof. Ladislav Rabušic a spoluautorkou Mgr. Eva Gregorová (Ehrenbergerová a Cicvárková 1995). Oběma patří díky za tuto inspiraci. Autorka také děkuje Mgr. Beatrici Chromkové Manea za kolegiální zpětnou vazbu u raných verzí tohoto textu a dvěma anonymním recenzentům za velice cenné připomínky, které byly do textu promítnuty. 
hodnotové postoje má česká společnost jako celek, jestli se tyto postoje liší u mladé a starší generace a jestli je možné očekávat, že se tyto postoje budou měnit s tím, jak budou mladší generace „stárnout“" a tvořit šedou budoucnost roku 2050.

Stárnutí české populace s sebou nese řadu hlubokých společenských změn. Tak tomu alespoň věrí česká veřejnost. Ve výzkum Ageismus 2007 se velká většina dotázaných (7090 \%) vyjádřila, že očekávaný nárůst podílu starších lidí ovlivní českou společnost v oblastech jako je důchodový systém, zdravotnictví, životní úroveň a výkonnost české ekonomiky (Vidovićová 2008). V těchto jmenovaných oblastech je možná či reálná změna relativně exaktně dokumentovatelná - např́klad změnou v HDP, výdaji na sociálně zdravotní systémy apod. Přesvědčení české veřejnosti o vlivu jejího „šednutí“ je ale úplně stejně silné i v oblastech, mnohem fluidnějších. Že se v budoucnu v přímém důsledku populačního stárnutí změní postoj společnosti ke starým lidem, tvrdí $80 \%$ lidí, a že se změní hodnoty, které uznávají lidé obecně, uvádí podobně vysokých $72 \%$ dotázaných. A jakkoliv se nám to může zdát neuvěřitelné, v prvním př́padě $36 \%$ a v druhém $20 \%$ dotázaných očekává, že tato změna bude $\mathrm{k}$ horšímu.

Tabulka 1: Očekávané důsledky zvyšujícího se podílu starších lidí na vybrané oblasti české společnosti ( $\vee \%)$

\begin{tabular}{|l|l|l|l|l|l|}
\hline & $\begin{array}{l}\text { Žádné } \\
\text { dúsledky }\end{array}$ & $\begin{array}{l}\text { (Velmi) } \\
\text { pozitivní }\end{array}$ & Půl na půl & $\begin{array}{l}\text { (Velmi) } \\
\text { negativní }\end{array}$ & Neví \\
\hline Důchodový systém & 2 & 3 & 18 & 69 & 8 \\
\hline Zdravotnictví & 4 & 4 & 26 & 57 & 9 \\
\hline Postoj veřejnosti ke starým lidem & 8 & 10 & 34 & 36 & 12 \\
\hline Životní úroveň občanů ČR & 10 & 6 & 37 & 37 & 10 \\
\hline Výkonnost české ekonomiky & 10 & 8 & 30 & 40 & 12 \\
\hline Hodnoty, které lidé uznávají & 15 & 15 & 37 & 20 & 13 \\
\hline
\end{tabular}

Zdroj: Vidovićová 2008: 174.

Není bez zajímavosti, že postoje uvedené v tabulce 1 mají, s výjimkou položky „postoje k seniorům“, jasný věkový gradient: mladší respondenti (18-29 let) jsou v očekávání vlivu populačního stárnutí mnohem pesimističtější než střední nebo starší (60-80 let) věkové kohorty. Jak ale interpretovat tyto výsledky v př́padě položky „hodnoty, které lidé uznávají“, kde negativní vliv očekává $31 \%$ nejmladších a $25 \%$ nejstarších respondentů? I když z těchto dat nemůžeme jasně vyextrahovat respondentovu percepci obsahu pojmu „hodnoty“, můžeme na základě teorie demografické paniky (Mullan 2002, Vidovićová 2006) usuzovat, že odpovědi na tuto baterii otázek se nesly v duchu „všechno bude špatně“. Čeká nás černá, respektive šedá budoucnost, zchudneme, nebudeme se rozvíjet a můžeme očekávat hodnotový (tj. morální) úpadek - i tak lze chápat vizi, kterou tyto postoje komunikují.

Každá společnost je ovšem tvořena jedinci a její vlastnosti lze odvozovat od vlastností a kvalit individuí, které sdružuje. ${ }^{2}$ A jak jsme již naznačili v úvodu, máme za to, že

2 Srovnej např́íklad debatu o nezbytnosti změn v osobním chování pro úspěšnou politiku „od změny klimatu až po obezitu“ (Reeves 2009: 5). 
strukturální vývoj společnosti lze (alespoň do určité míry) odhadnout na základě vývoje individuálních hodnot a postojů, které, stejně jako společnost jako celek, prochází určitým cyklickým, respektive spirálním vývojem. V akademické debatě není dosaženo konsenzu, zdali se hodnotový a postojový systém jedince v průběhu (a zejména závěru) jeho individuální životní trajektorie upevňuje, rigidizuje, anebo naopak převažuje tendence ke změnám a určité flexibilizaci. V jistém smyslu se jedná o klasickou debatu mezi teoriemi vyvázání, aktivity a kontinuity (viz např́klad Sýkorová 2007). Kogan (1990 in Atchley 1997) uvádí, že z dosavadních studií vyplývají dva hlavní závěry: 1) osobnost udržuje určitou kontinuitu v tom, že typické myšlenky, motivy a emoce mají tendenci být v průběhu času stabilní; a 2) dochází také k významné evoluci osobnosti během dospělosti, takže dlouhodobá korelace mezi osobnostními rysy (personality traits) raného mládí a pozdní dospělosti je jen skromná. Po období středního věku, kdy se ještě mohou projevovat určité adaptační systémy silněji, osobnostní stabilita významně převažuje nad osobnostní změnou. Lidé se snaží jednat konzistentně vzhledem ke své minulosti a osobnost je postupem času takto „institucionalizována“ (tamtéž: 121). Autor uzavírá, že debata „stabilita vs. změna“ vychází především z rozdílných úrovní studia. Starší lidé zažívají velký podíl kontinuity v „globálních“ aspektech osobnosti, ale zároveň prožívají velký podíl změn $\mathrm{v}$ „detailech“ sdružených pod oněmi globálními pojmy. Globální aspekty osobnosti přitom mají tendenci přetrvávat v různých sociálních situacích i přes změny v detailech každodenního života. Na datech European Values Study se pokusíme tuto debatu obohatit o dimenzi morálních postojů.

Pokud nás psychologové učí, že morálka je otázkou postupného vývoje osobnosti, sociologové dodávají, že morálka jako soubor hodnot, norem a vzorů chování je, alespoň do určité míry, variabilní a kulturně relativní. Morálka reguluje vztahy mezi jednotlivci, mezi jednotlivcem a společenskou skupinou a mezi skupinami vzájemně a využivá $\mathrm{k}$ tomu různé intenzity formalizace - od neformální sociální kontroly po legislativou ustanovené zákazy a př́kazy, právní kodex (Havelková a Vodáková 1996). Z řečeného je patrné, že morálka je ze své podstaty velice dynamický koncept a její různé úrovně vývoje se mohou kř́ižit na mikro, mezo i makro úrovni v množství kombinací a variací. Obecně se má za to, že hlavní morální základy jsou formovány a utvrzovány v rané dospělosti (Piaget 1983 in Macdonald a StuartHamilton 1996). To je konečně i jeden z hlavních cílů rané socializace. Vývoj člověka a jeho socializace jsou ovšem otevřeným procesem bez jasné, chronologicky definovatelné nebo věkové hranice (Macdonald a Stuart Hamilton 1996, Stuart-Hamilton 1999, Erikson 1999). Změny v lidských životech a změny v sociálních strukturách a institucích se přitom ovlivňují navzájem. Jak upozornila především Rileyová (1987), proměny lidských životů i struktur se dějí relativně odděleně, ale také ve vzájemné závislosti. Dochází tak k odlišení kohortních zkušeností, nebot' s tím, jak se společnost(i) mění, př́slušníci různých kohort stárnou „různými způsoby“. Dynamická souhra mezi životy a strukturami obsahuje „přirozené“ asynchronie, rozdíly v časování, což produkuje napětí u jedinců i v sociálních institucích. Zatímco lidský život má svoji relativně stabilní biologickou trajektorii od narození (od početí) do smrti, časování strukturálních procesů žádným srovnatelným rytmem nedisponuje a prochází skrze zcela odlišné historické přeměny. Rileyová (1987) v tomto kontextu odkazuje na Sorokinovo (1941) tvrzení, že unilineární vývoj či pokrok neexistuje (k této diskusi podrobněji viz Vidovićová 2008: 18n). Tato změt' systémů představuje pro sledování změny morálního 
smýšlení v čase zvláštní výzvu. Je totiž nutné od sebe odlišit dopady velkých sociálních změn, dynamiku mezi minulostí a budoucností a změny způsobené vývojovými vzorci individuální změny během životního cyklu (Dannefer a kol. 2005).

Př́iklad kontinuální vývojové dynamiky zdokumentovaly např́iklad Vidovićová a Gregorová (2008) při výzkumu příčin věkové diskriminace. Popisují jej jako fenomén „nostalgie ze starých dobrých časů“. Senioři a seniorky, komunikační partneři v citovaném výzkumu, upozorňovali na úpadek hodnot, nedostatek respektu a úcty u mladých a používali obraty jako „to dřív tak nějak nebylo“, „dneska už to není“, „ta omladina je i docela jináč vychovávaná“ (tamtéž: 19). Jen těžko bychom takový výrok očekávali z úst nějakého teenagera, ale přitom v úvodu uvedená obava mladých lidí o morální (hodnotovou) kvalitu budoucnosti, tj. obavy, že dobře už bylo, a to co přijde, se ponese ve znamení úpadku, je jen druhou stranou téže mince. Ciceronův povzdech „O tempora! O mores!“", obsažený v názvu této statě, odráží obdobnou nespokojenost a dává tušit, že se jedná o nadčasový fenomén.

\section{Metodologie}

Pro účely vytyčeného zkoumání jsme si položili otázku, zdali se liší morální postoje mladých a starších lidí, zdali existuje něco jako generační či věkově vázaná morálka a zdali dochází ke změně v morálních kvalitách společností v průběhu kalendářního času. Morálku jako předmět našeho zkoumání operacionalizujeme tak, jak jej vystihlo šetření European Values Study (blíže o tomto výzkumu viz editorial tohoto čísla) v baterii otázek popisujících jednání a situace více či méně od morálních norem odchýlených. Situace a jednání byly uvedeny otázkou s následujícím zněním: „Řekněte prosím, co z následujících možností a do jaké míry je ospravedlnitelné“. Varianty odpovědí respondenti zaznamenávali na škále od 1 do 10 , kde hodnota 1 reprezentuje „nikdy“ a 10 odpovídá odpovědi „vždy“. Platí tedy, že čím vyšší skóre v této proměnné, tím vyšší ospravedlnitelnost, respektive vyšší míra liberálnosti respondenta $\mathrm{v}$ dané oblasti/situaci. Baterie otázek se $\mathrm{v}$ jednotlivých letech šetření měnila s tím, jak se objevovaly nové ožehavé otázky ve veřejné diskusi (např́klad umělé oplodnění, genetická manipulace potravin, trest smrti apod.), zatímco jiné již v posledním dostupném roce šetření zahrnuty nebyly. Vesměs se přitom jedná o situace, které byly v letech 1991 a 1998 hodnoceny jako nejméně ospravedlnitelné (vražda z politických důvodů, ř́zení pod vlivem alkoholu, pohlavní styk s nezletilým, odhazování odpadků, rychlá jízda v obci). V dalších analýzách proto s položkami, které nebyly zjišt'ovány v posledním dostupném roce (2008), v tomto textu nepracujeme. Pro účely tohoto výzkumu sledujeme pouze dva krajní časové body disponibilního šetření, tedy roky 1991 a 2008. Není-li předmětem úvah meziroční srovnávání a není-li výslovně řečeno jinak, jsou v textu prezentovaná data za rok 2008. Pro analýzu seniorské populace jsme arbitrárně zvolili hranici 60 let věku. Mezinárodní srovnání provádíme z váženého souboru EVS - Europe (verze červen 2010). K analýzám jsme využili program SPSS 16.0.

Rádi bychom čtenáře upozornili, že tématem stati je sice morálka jako hodnotový systém pravidel, ale v dalším textu spíše operujeme s pojmy jako liberálnost vs. konzervatismus, čímž se snažíme vyjádřit tendence při hodnocení sledovaných situací bez toho, že bychom explicite definovali nějaký postoj jako morální a jiný jako nemorální. Referujeme tak o určité 
formě otevřenosti či uzavřenosti v tradičním porozumění těm konceptům, bez př́mé návaznosti na jejich politickou konotaci. Obdobně jsme si vědomi, že se dopouštíme určitých zkreslení či manipulací, když v textu používáme „ne/ospravedlnitelné“ a „odsouzení (méně) hodné" synonymicky. ${ }^{3}$

\section{Morální postoje české populace}

Již při prvním pohledu na př́slušné tabulky v Pramenné publikaci EVS (Rabušic a Hamanová 2009: 286-306) bychom mohli vyslovit několik obecných závěrů platných pro většinu sledovaných položek:

- podíl osob, které považují sledované situace za neospravedlnitelné, meziročně klesá;

- podíl osob, které považují sledované situace za ospravedlnitelné vždy, se zvyšuje, ovšem ne v každém případě dramaticky; v meziročním srovnání je nejdynamičtější kategorií kategorie „středová““,4

- hodnocení v letech 1991 a 1999 si jsou obvykle podobná, významné rozdíly jsou až v porovnání s rokem 2008;

- podíl osob, které považují sledované situace za neospravedlnitelné, je významně vyšší ve vyšších věkových kategoriích, ale věkové rozdíly na druhém konci škály („ospravedlnitelné vždy") nelze vždy považovat za významné (tj. větší než $5 \%$ );

- zřetelnými liberálními postoji se osoby ve věkové kategorii 18-29 let odlišují od ostatních věkových skupin ve všech sledovaných letech.

Přestože tyto body reflektují také základní výsledky dostupné ze zahraničí (zejména Halman 1995), nacházíme i specifické a relativně závažné výjimky. Než se k nim dostaneme, zrekapitulujeme $\mathrm{v}$ tabulce 2 přehled všech dotazovaných situací a jejich hodnocení $\mathrm{v}$ jednotlivých letech.

Umělé oplodnění, trest smrti, rozvod a do jisté míry potrat, euthanasie a homosexualita patří mezi relativně ospravedlnitelné formy jednání. Oproti tomu užívání drog, zneuživání státní podpory a tzv. ,joyriding“ uzavírají řebříček jako jednání nejvíce odsouzeníhodné. Musíme ovšem podtrhnout, že ani v př́ípadě rozvodu není průměrná hodnota významně vyšší než pět bodů, což lze slovně opsat jako „ospravedlnitelné někdy ano, někdy ne“, „tak na půl“", či „záleží na situaci“.

3 Hovoříme o morálce a ta není hodnotově neutrální pro respondenty, pro čtenáře, ale ani pro samotnou autorku textu. Navíc předmět zkoumání vystupuje jako určitá forma sociálního vztahu a hodnotové konotace tak mají nejen sledované situace, ale hodnotové soudy mohou vyvolávat i postoje lidí k nim (,,potrat je špatný a ti, co schvalují/ospravedlňují potraty, dělají špatnou věc“). Jedná se přitom o klasický nábožensko-filozofický dualismus hříchu a hř́ínníka. Tuto interpretativní stránku tvorby toho textu se tak snažíme průběžně reflektovat v použitém jazyce ve snaze o maximalizaci jeho hodnotové neutrality.

4 Středová kategorie byla vytvořena součtem odpovědí 4, 5, 6, a 7 na desetistupňové hodnotící škále (Rabušic a Hamanová 2009) . 
Tabulka 2: Míra ospravedlnitelnosti specifického jednání (průměry)

\begin{tabular}{|l|c|c|c|c|c|}
\hline & 1991 & 1999 & 2008 & $\begin{array}{c}\text { Rozdíl mezi } \\
2008 \text { a 1991 }\end{array}$ & $\begin{array}{c}2008 \text { Rozdíl mezi } \\
\text { EVS Evropa a Cz }\end{array}$ \\
\hline $\begin{array}{l}\text { Umělé oplodnění dárcem nebo oplodnění ze } \\
\text { zkumavky (IVF) }\end{array}$ & - & - & 6,6 & - & 0,8 \\
\hline Trest smrti & - & - & 5,6 & - & 1,8 \\
\hline Rozvod & 5,2 & 5,9 & 5,6 & 0,5 & 0,4 \\
\hline Potrat & 5,1 & 5,5 & 5,3 & 0,2 & 1,2 \\
\hline $\begin{array}{l}\text { Euthanasie (ukončení života nevyléčitelně } \\
\text { nemocného) }\end{array}$ & 4,0 & 5,4 & 5,3 & 1,3 & 1,0 \\
\hline Homosexualita & 3,8 & 5,5 & 4,9 & 1,1 & 1,3 \\
\hline Provozovat přležitostný sex & - & 2,9 & 3,5 & - & 0,4 \\
\hline Genetická manipulace potravin & - & - & 3,1 & - & 0,5 \\
\hline Sebevražda & 2,8 & 2,9 & 3,4 & 0,6 & 1,0 \\
\hline $\begin{array}{l}\text { Vědecké experimenty na lidských zárodcích } \\
\text { (embryích) }\end{array}$ & - & - & 3,0 & - & 0,4 \\
\hline Lhát ve vlastním zájmu & 2,9 & 2,8 & 3,2 & 0,3 & 0,4 \\
\hline $\begin{array}{l}\text { Platit za služby v hotovosti a bez dokladu } \\
\text { a vyhýbat se tak placení daní }\end{array}$ & - & 2,4 & 3,4 & - & 0,3 \\
\hline Jako ženatý, vdaná mít milostný poměr & 2,8 & 2,7 & 3,0 & 0,2 & 0,5 \\
\hline $\begin{array}{l}\text { Vyhnout se placení jízdného ve verejné } \\
\text { dopravě }\end{array}$ & 2,6 & 2,8 & 2,9 & 0,3 & 0,1 \\
\hline Prostituce & 2,1 & 3,0 & 3,2 & 1,0 & 0,5 \\
\hline $\begin{array}{l}\text { Přijmout od někoho úplatek za výkon svých } \\
\text { povinností }\end{array}$ & 2,2 & 2,2 & 2,6 & 0,4 & 0,6 \\
\hline Šidit na daních, když je přilležitost & 1,8 & 2,0 & 2,5 & 0,7 & 0,0 \\
\hline $\begin{array}{l}\text { Nasednout do auta, které patří někomu jinému, } \\
\text { a z legraces sím odjet }\end{array}$ & 2,0 & 1,9 & 2,2 & 0,2 & 0,5 \\
\hline Požadovat státní podporu a nemít na ni nárok & 1,7 & 1,8 & 2,4 & 0,7 & $-0,1$ \\
\hline Uživat drogy, napríklad marihuanu nebo hašiš & 1,3 & 1,6 & 2,1 & 0,8 & 0,2 \\
\hline Pón & \\
\hline
\end{tabular}

Poznámka: Čím vyšši hodnota, tím vyšší ospravedlnitelnost dané situace. Situace jsou v tabulce seřazeny dle průměrné hodnoty za všechny sledované roky od nejvíce ospravedlnitelných až po ty nejméně ospravedlnitelné. Značka „-" nahrazuje hodnoty v letech, kdy daná položka nebyla dotazována. Hodnoty se mohou mírně lišit od pramenné publikace (Rabušic a Hamanová 2009) v důsledku zaokrouhlování. Celoevropský průměr je vypočítán za 38 zúčastněných zemí, bez České republiky.

Všechny sledované situace a jednání tak $\mathrm{v}$ tomto střednědobém pohledu sedmnácti let zůstávají hodnoceny jako více či méně sociálně patologické, s jedinou výjimkou umělého oplodnění. Na druhou stranu všechny položky mezi krajními sledovanými lety „posílily“ v ospravedlnitelnosti, což naznačuje obecně narůstající liberalitu, respektive relativitu v přístupu ke sledovaným položkám. Mezi položkami sledovanými ve všech třech letech se o více než jeden bod zvýšila ospravedlnitelnost euthanasie, homosexuality a prostituce, mezi nověji sledovanými položkami pak do tohoto seznamu patř́ i vyhýbání se placení daní 
obchodováním bez účetních dokladů. I přes tuto určitou univerzalitu existují rozdíly hodnocení co do rozptylu, tak i do dynamiky těchto hodnot mezi sledovanými lety. Mezi nejvíce a nejméně (respektive nikdy a nejčastěji) ospravedlnitelným jednáním je rozptyl 5,1 bodu, tedy $51 \%$ nabídnuté škály. V meziročním srovnání paradoxně nejvyšší „zisk“ a zároveň i významnou „ztrátu“ zaznamenala položka „homosexualita“, jež mezi lety 1991 a 1999 získala (1,7 bodů) a mezi 1999 a 2008 ztratila ( 0,7 bodů). Podobně nestandardní, respektive nelineární vývoj směrem $\mathrm{k}$ větši liberálnosti můžeme, i když v menší míře, vysledovat v tabulce 2 i u položek ,prostituce“ nebo „lhaní ve vlastním zájmu“.

Poslední sloupec tabulky 2 uvádí prosté rozdíly v průměrných hodnotách mezi ČR a ostatními státy „velké“ Evropy. S drobnou výjimkou zneužívání státní podpory jsou Češi a Češky liberálnější ve většině hodnocených situací. Můžeme pouze spekulovat, že svoji roli zde hraje xenofobní tendence spojovat zneužití státní podpory s minoritní populací, což umožňuje vyhranit svůj postoj vůči tzv. „out-group“.5 Relativně nejvíce se odlišujeme od ostatních států ve vyšší míře ospravedlnitelnosti trestu smrti a homosexuality. K pozici ČR mezi státy Evropy se však ještě vrátíme v samostatném oddíle níže.

I když de facto všechny položky odrážejí morální kvintesenci naší kultury vyjádřenou v biblickém Desateru a zejména jeho nejznámější části: nezabiješ, nesesmilníš, nepokradeš, nevydáš křivého svědectví a nepožádáš manželky bližního svého, je možné mezi nimi identifikovat obecnější oblasti či typy jednání. K této identifikaci jsme využili faktorovou analýzu, jejímž výsledkem jsou tři základní skupiny. ${ }^{6}$ První, nejobsáhlejší tematickou skupinu by bylo možné charakterizovat zastř̌šujícím pojmem „,podvody“. Sdružují se zde jednání, která obchází nějaká formální, legislativní, ale i neformální pravidla (jako například věrnost v manželství). Jsou zde koncentrována porušení pravidel ve smyslu lhaní a zatajování, hledání vlastního prospěchu a (,zvráceného“) blaha. Pro tuto kategorii přebíráme Halmanův (1995) pojem „občanská morálka“ (civic morality). Druhá kategorie, jejíž význam lze charakterizovat také jako ohrožení (tradiční) rodiny, obsahuje situace jako potrat, rozvod, homosexualitu a alternativní formy oplodnění. Tato jednání jsou vlajkovou lodí modernizačních tendencí ve společnosti. Patří mezi ta nejčastěji ospravedlňovaná, často ve veřejném diskurzu spojovaná s nálepkou „normální“ či „,moderni““. Jsou to do značné míry viditelné, veřejné situace odehrávající se na těle, jakási veřejná tělesnost. Halman pro obdobný př́ípad užívá označení „tolerance“ (permissiveness) a argumentuje, že se nejedná o (ne)dostatek morálky, ale o větší či menší míru akceptace, že jiní lidé mohou mít odlišné standardy (tamtéž: 428). ${ }^{7}$ Poslední, třetí kategorie s poněkud širokým názvem „moderní (morální) rizika“ shrnuje

5 Data EVS této teorii ovšem nenahrávají. Žádnou souvislost mezi odmítnutím Romů mezi svými sousedy (tj. zástupným indikátorem xenofobního postoje) a ospravedlnitelností zneužívání dávek nenacházíme v Evropě ani v českých datech.

6 Faktorovou analýzu jsme realizovali pouze na datech z roku 2008. Využili jsme Principal Component Analysis s rotací Varimax. KMO test dosáhl hodnoty 0,885 . Ve třech extrahovaných faktorech je vysvětleno 61,9 \% rozptylu. Zahrnuty byly pouze položky s faktorovou zátěží vyšší než 0,4.

7 Jak ještě ukážeme dále, Halman (1995) na mezinárodních datech vyextrahoval pouze dva faktory s velice významově obdobným, ovšem nikoliv identickým sycením. Pro účely sjednocení textu však využíváme Halmanova označení i pro naše faktory. Čtenáři později znovu připomeneme, že se jedná o vnitřně ne zcela identické kategorie. 
situace vědeckých experimentů na embryích, genetickou manipulaci potravin a trest smrti. Tento oddíl zastřešuje jednání odrážející tendenci moderního člověka přebírat nadvládu v oblastech tradic vyhrazených židovsko-křest’anskému Bohu - Stvořiteli, populárně někdy charakterizované jako „hrát si na Boha“ nebo ,jít proti př́rodě“. Zároveň se jedná o situace nejméně ,jasné“, prozkoumané, zřejmé. Definování pro a proti probíhá ve stále neuzavřené a velice živé diskusi nejen mezi veřejností, ale i mezi názorovými vůdci (opinion-makers) a vědomostní elitou. Bylo-li dosaženo alespoň dílčího hodnocení objektivních dopadů těchto aktivit, zůstává pro veřejnost př́liš složité a pro běžného aktéra nedostupné. To, že se soustředí kolem středních hodnot použité škály, vystihuje snad právě onu nejasnost a fluidnost. Nemáme k dispozici data za minulá období, ale můžeme se domnívat, že do budoucna bude tato kategorie patřit mezi ty nejvíce dynamické, $\mathrm{s}$ tím jak $\mathrm{v}$ budoucnu budou názory na tato témata krystalizovat a usazovat se v návaznosti na pokračující ideologické (ideové) diskuse.

Postoje určující míru ospravedlnitelnosti těchto kategorií jsou vyplétány ze sítě socioekonomických charakteristik každého jednotlivce, kdy tyto charakteristiky reprezentují určité formativní tlaky společnosti a jejích institucí. Obvyklými koreláty, zejména v oblasti sexuální a rodinné morálky (Treas 2002), jsou vzdělání, socioekonomický status, participace na organizované religiozitě a pohlaví. Výsledky publikované Rabušicem a Hamanovou (2009) navíc poukazují na význam regionu a velikosti obce. Pro naše účely jsme v tabulce 3 provedli jednoduché rozdělení průměrné výše jednotlivých indexů podle základních charakteristik respondenta a doplnili jsme tabulku o průměrnou hodnotu odpovědi pro tři dílč́i situace, typické zástupce jednotlivých indexů.

Tearsová (2002) či Scottová (1998) ve svém výzkumu sexuální morálky v USA popsaly určité principy, které otevřenost ve vybraných otázkách spoludeterminují. Podobné souvislosti nacházíme i v české společnosti. Například ženy jsou obvykle méně otevřené vůči předmanželskému a mimomanželskému sexu, zato jsou více tolerantní vůči homosexualitě. Vzdělání má určitý lineární vliv na větší liberalitu, ale v prrípadě faktoru „občanské morálky“ vede opačným směrem než u druhých dvou indexů: podvody jsou ospravedlnitelnější pro lidi s nižším vzděláním. Tam, kde se jedná spíše o modernizační změnu a flexibilitu životních stylů, je lídrem nových hodnot vzdělaná elita. Stoprocentně hypotéza o elitách jako názorově otevřenějších platí při pohledu skrze kategorie rodinného př́ijmu. Nesmírně zajímavé jsou diference co do regionu, ve kterém respondent žije. Při podrobnějším zkoumání bychom viděli, že Praha ve většině př́ípadů „odskakuje“ od zbytku Čech a svojí liberálností často několikanásobně převyšuje region moravský. ${ }^{8} \mathrm{O}$ to zajímavější je obrázek nabízející se pro velikost sídel, kdy lidé žijící v menších sídlech jsou o něco ochotnější ospravedlnit podvody a lhaní, ale $\mathrm{v}$ dalších otázkách morálky se velikost bydliště nezdá zakládat jednotnou platformu pro otevřenost/uzavřenost. Zcela v souladu s očekáváním ale morálku ovlivňuje př́slušnost $\mathrm{k}$ církvi, tedy zástupná proměnná pro organizovanou religiozitu, i subjektivní

$8 \quad$ Např́ílad v Praze konzumaci drog jako vždy ospravedlnitelnou hodnotí $9 \%$ respondentů, na Moravě je to jen jedno procento; sebevraždu ospravedlní $23 \%$ Pražanů, ale jen $5 \%$ Moravanů, v případě př́ležitostného sexu jsou regionální hodnoty absolutní ospravedlnitelnosti pro Prahu $21 \%$ a pro Moravu $5 \%$. Svůj vliv zde nepochybně hraje i religiozita, která je v Praze nižší, a vzdělání, které je v hlavním městě naopak v průměru vyšší než v moravském regionu. 
sebehodnocení respondenta jako „,veřícího“ či „neveřícího“ (zde nepublikováno). Lidé religióznější vykazují nižší míru liberality ve všech prezentovaných položkách, i když míra rozdílu mezi př́slušníky církví a nábožensky neorganizovanými variuje od téměř dvou bodů $\mathrm{v}$ př́ipadě potratu a 1,5 bodu $\mathrm{v}$ př́ípadě rozvodu (oba index tolerance), až po necelého půl bodu ve třech položkách indexu „občanské morálky“ (šidit na daních, čerpat neoprávněnou státní podporu a ujet s autem $\mathrm{z}$ legrace).

Tabulka 3: Průměrné hodnoty škály ospravedlnitelnosti dle charakteristik respondenta

\begin{tabular}{|c|c|c|c|c|c|c|}
\hline & $\begin{array}{l}\text { Občanská } \\
\text { morálka } \\
\text { (index) }\end{array}$ & $\begin{array}{l}\text { Tolerance } \\
\text { (index) }\end{array}$ & $\begin{array}{l}\text { Moderní } \\
\text { rizika } \\
\text { (index) }\end{array}$ & $\begin{array}{c}\text { Jako ženatý, } \\
\text { vdaná mít milostný } \\
\text { poměr }\end{array}$ & $\begin{array}{l}\text { Homo- } \\
\text { sexualita }\end{array}$ & $\begin{array}{c}\text { Genetická } \\
\text { manipulace } \\
\text { potravin }\end{array}$ \\
\hline Celkem & 2,7 & 5,6 & 3,9 & 3,0 & 4,9 & 3,1 \\
\hline \multicolumn{7}{|l|}{ Pohlaví: } \\
\hline Muž & 3,0 & 5,6 & 4,1 & 3,4 & 4,7 & 3,4 \\
\hline Žena & 2,5 & 5,6 & 3,7 & 2,7 & 5,0 & 2,9 \\
\hline \multicolumn{7}{|l|}{ Vzdělání: } \\
\hline Základní & 2,8 & 5,1 & 3,7 & 2,8 & 4,2 & 2,9 \\
\hline vyučen(a) & 2,8 & 5,4 & 3,9 & 3,0 & 4,5 & 3,1 \\
\hline SŠ & 2,7 & 5,8 & 3,9 & 3,1 & 5,2 & 3,1 \\
\hline VŠ & 2,5 & 6,1 & 4,1 & 3,2 & 5,5 & 3,7 \\
\hline \multicolumn{7}{|l|}{ Rodinný př́jem: } \\
\hline podprůměrný & 2,2 & 4,8 & 3,5 & 2,5 & 4,0 & 2,6 \\
\hline průměrný & 2,6 & 5,7 & 3,9 & 2,8 & 5,0 & 3,1 \\
\hline nadprůměrný & 3,1 & 5,9 & 4,0 & 3,4 & 5,2 & 3,5 \\
\hline \multicolumn{7}{|l|}{ Region: } \\
\hline Praha & 3,0 & 6,6 & 4,1 & 3,4 & 6,4 & 3,4 \\
\hline Čechy & 3,0 & 5,8 & 4,1 & 3,2 & 4,9 & 3,5 \\
\hline Morava & 2,2 & 5,0 & 3,5 & 2,5 & 4,4 & 2,4 \\
\hline \multicolumn{7}{|l|}{ Velikost sídla: } \\
\hline do 4999 & 3,0 & 5,6 & 3,9 & 3,2 & 4,8 & 3,3 \\
\hline $5000-19999$ & 2,7 & 5,5 & 4,0 & 2,8 & 4,4 & 3,2 \\
\hline $2000-99999$ & 2,5 & 5,7 & 4,0 & 2,9 & 4,8 & 3,1 \\
\hline 100000 a více & 2,5 & 5,6 & 3,7 & 3,0 & 5,3 & 2,9 \\
\hline \multicolumn{7}{|c|}{ Příslušnost k církvi: } \\
\hline Ano & 2,2 & 4,6 & 3,4 & 2,2 & 4,0 & 2,6 \\
\hline $\mathrm{Ne}$ & 2,9 & 6,0 & 4,1 & 3,4 & 5,2 & 3,3 \\
\hline
\end{tabular}

Poznámka: Data jsou za rok 2008. Podbarvená buňka ukazuje na nejliberálnější postoj v dané podskupině. 
Naším skutečným zájmem v tomto textu je ale zjištění souvislostí mezi mírou ospravedlnitelnosti a věkem respondenta. Prostým pohledem na Pearsonův koeficient charakterizující těsnost vztahu mezi věkem respondenta a jednotlivými položkami shledáváme, že až na výjimky existuje středně silná, záporná asociace. To naznačuje, že čím vyšší věk respondenta, tím nižší ochota jednotlivé situace hodnotit jako ospravedlnitelné. Zmiňovanými výjimkami, kde je asociace s věkem respondenta nulová nebo velmi slabá, jsou trest smrti a nově sledované situace, tj. experimenty na lidských zárodcích, genetická manipulace potravin a oplodnění ze zkumavky. V těchto případech jsou senioři zhruba stejně „,ne/liberální“ jako mladší generace. Naopak v případě př́iležitostného sexu, prostituce a užívání drog patří senioři mezi největší ,puritány“. Jen snad pro zajímavost dodejme, že meziročně síla koeficientu mezi věkem a ospravedlnitelností prostituce klesla, zatímco mezi věkem a užíváním drog posílila. ${ }^{9}$ Následující grafy znázorňují souvislost s věkem respondenta pro rok 2008.

Graf 1: Prưměrné hodnoty indexů dle věkových kategorií respondenta (pouze rok 2008)

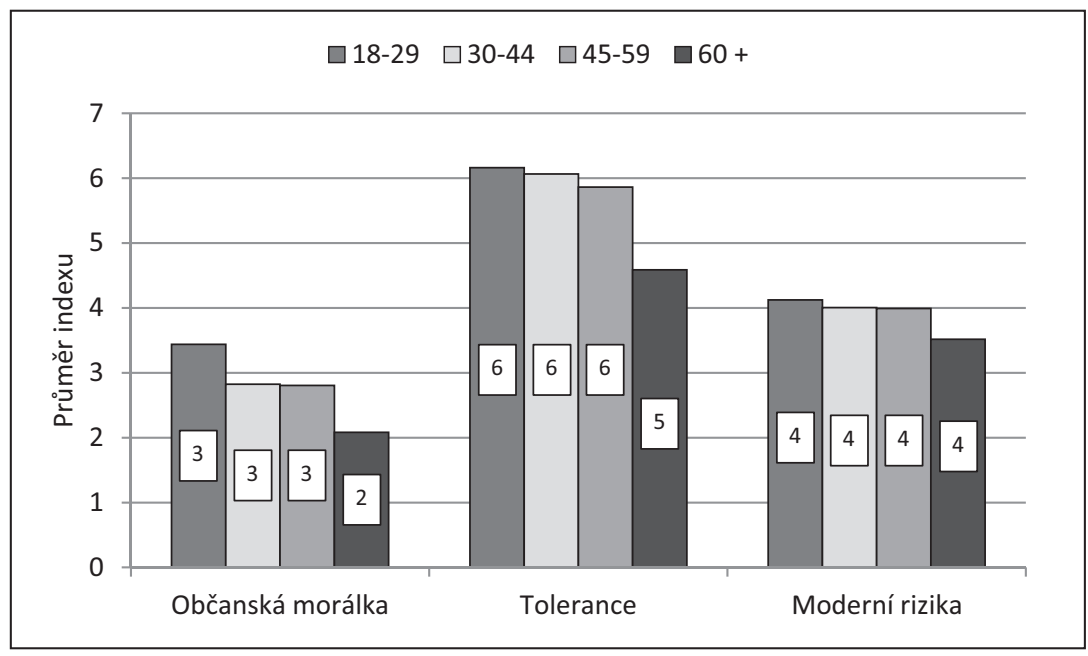

Výše uvedený graf 1 pouze znovu vykresluje již výše uvedenou informaci, že míra otevřenosti je nižší s podvody než s moderními riziky nebo ohrožením tradičních rodinných struktur a klesá s věkem respondenta. Následující graf 2, prezentující stejné hodnoty tentokrát detailněji dle věkových jednotek ovšem tato tvrzení relativizuje. Pokud bychom se dívali

Ordinální koeficient Gamma byl v roce 1991 pro prostituci -0,43 a v roce 2008 klesl na -0,31; pro drogy -0,34 (1991) a stoupá na -0,54 (2008). Celkem u 14 položek, u kterých můžeme toto srovnání provést, došlo $\mathrm{k}$ poklesu síly asociace ve čtyřech př́ípadech, zhruba stabilní hladinu držely další čtyři př́ípady a u zbylých šesti položek evidujeme nárůst. Nelze tedy ani jednoznačně říci, že by vývoj společnosti jednosměrně přispíval ke zvýznamňování věku v upevňování morálních soudů. Pro hodnocení některých jednání je věk důležitější, ospravedlnění jiných se naopak stává univerzálnějším, na věku méně závisným procesem. 
pouze na hrubě zprůměrovaný ukazatel, pak by bylo možné říci, že vysoká tradiční morálka není něco, co nás potká před smrtí, ale je spíše charakteristikou určité kohorty. Na druhou stranu mezi seniory panuje, pro někoho možná až překvapivě vysoká, heterogenita, v grafu 2 vyjádřená velkou oscilací. Nejsilněji je tato variabilita vyjádřená v př́ípadě tolerance a moderních rizik. Je možná jistým paradoxem, že se jedná právě o ty dvě oblasti, které jsou explicite definovatelné jako porušení židovsko-křest’anské tradiční morálky, která bývá nezř́́dka spojována právě se seniory.

Graf 2: Průměrné hodnoty indexů dle jednotek věku (pouze rok 2008)

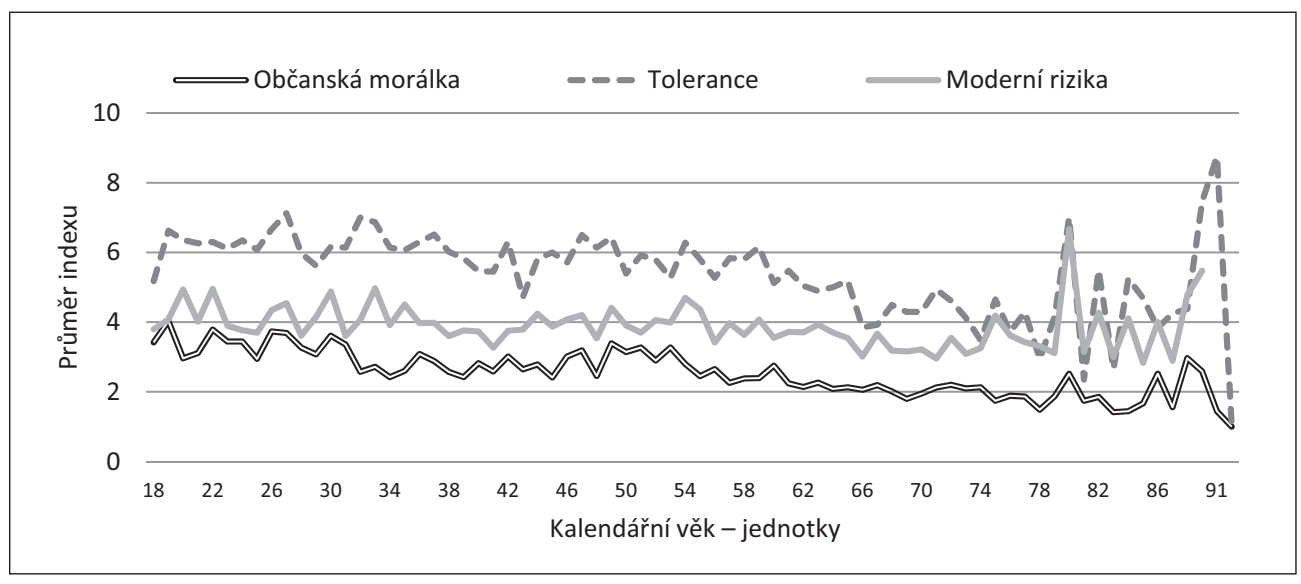

Jednou z možných interpretací, kterou můžeme nabídnout, je teorie zvyšující se heterogenity individuálních charakteristik v průběhu životní dráhy. Medicína nás například učí, že lidská bytost začíná své bytí jako zcela standardizované embryo, což pomáhá gynekologům $\mathrm{s}$ relativně velkou přesností určit délku těhotenství. V průběhu života jsme však vystaveni nekonečné řadě kombinací intervenujících vlivů - at' už z fyzického prostředí, či společnosti - a jejich formativní vliv má ve stář́ tendenci kulminovat. Oproti běžné představě tak senioři nejsou homogenní skupinou, ale naopak skupinou vykazující tendenci k nejvyšší míře rozmanitosti. Vrstvení životních zkušeností a podmínek může bezpochyby formovat i pohled na společnost ve smyslu její morálky a vyústit v častěji relativizující a méně uniformní postoj. Podobné grafické vyjádření za data seniorů roku 1991 (zde nepublikováno) ale takto výrazně „roztřesený ocásek“ nemá. Můžeme se tedy domnívat, že demokracie a svoboda voleb životního stylu k této rozmanitosti významně přispěla. Druhým možným vysvětlením je samožrejmě i technická otázka menšího počtu respondentů v těchto věkových kategoriích. ${ }^{10}$

10 V roce 2008 bylo respondenti̊ nad 60 let 477 , tj. asi $30 \%$. V kategorii $80+$ bylo dotazováno již pouze 48 respondentů. Průměr pro respondenty $60+$ např́klad v indexu tolerance je 4,6 se směrodatnou odchylkou 2,5; u respondentů $80+$ je směrodatná odchylka 2,7 od průměru 4,6 bodů. Směrodatná odchylka pro celý soubor je taktéž 2,5 bodů. 


\section{Generační souvislosti hodnotových postojů}

Pro pokus o zodpovězení otázky po mezikohortních a strukturních vlivech si vypomůžeme ilustrací rozdílů v postojích mezi třemi různými věkovými skupinami ve dvou časových bodech. Naše data samozřjejmě nemají longitudinální povahu per se, nesledují v čase stejné jedince, ale pro náš účel snad postačí, že budeme sledovat stejné věkové skupiny v rozdílných časových bodech, podobně jako to dělali Abramson a Inglehart (1992) při sledování mezikohortních rozdílů $\mathrm{v}$ postmaterialismu. Kvưli chybějícím datům se dále nevěnujeme indexu „moderních morálních rizik“.

Srovnáním různých věkových skupin v každém roce získáváme mezigenerační změny (inter-generational shifts), kdežto změny uvnitř generací (intra-generational) budou zjevné tehdy, když různé věkové skupiny srovnáme v čase (Halman 1995). Pro zjednodušení analýz jsme se opět soustředili pouze na dva krajní časové body, rok 1991 (T1) a 2008 (T2). Z logiky časového vývoje jsou mladí senioři v čase T1 staršími seniory v čase T2, střední generace se „mění“ na seniory a junioři na dospělé. Pro lepší ilustraci posloupnost věků, tedy jak s každým rokem stárnou jednotlivé skupiny, znázorňujeme v pomocné tabulce 4: šedesátníci roku 1991 mají v roce 2008 již 77 let, dvacetišestiletí v roce 1991 slaví v roce 2008 čtyřicáté tř̌etí narozeniny atd. Abychom získali dostatečný počet respondentů pro účely srovnání, definovali jsme základní pětileté kohorty, které označujeme následovně: mladí senioři ve věku 60-64 let, střední generace (dospělí) ve věku 43-47 let a junioři ve věku 26-30 let.

Tabulka 4: Souslednost věkových kohort mezi lety šetření EVS (jednotky věku)

\begin{tabular}{|l|c|c|c|c|c|c|c|c|c|c|c|c|c|c|c|c|c|c|}
\hline & 1991 & 1992 & 1993 & 1994 & 1995 & 1996 & 1997 & 1998 & 1999 & 2000 & 2001 & 2002 & 2003 & 2004 & 2005 & 2006 & 2007 & 2008 \\
\hline Senioři & 60 & 61 & 62 & 63 & 64 & 65 & 66 & 67 & 68 & 69 & 70 & 71 & 72 & 73 & 74 & 75 & 76 & 77 \\
\hline Dospělí & 43 & 44 & 45 & 46 & 47 & 48 & 49 & 50 & 51 & 52 & 53 & 54 & 55 & 56 & 57 & 58 & 59 & 60 \\
\hline Junioři & 26 & 27 & 28 & 29 & 30 & 31 & 32 & 33 & 34 & 35 & 36 & 37 & 38 & 39 & 40 & 41 & 42 & 43 \\
\hline
\end{tabular}

Odpověd' na otázku po mezigeneračních změnách jsme již nastínili v předchozím textu závěrem, že starší kohorty byly v roce 1991 i 2008 skrupulóznější než kohorty mladší. Na druhou otázku, zdali jsou silnější vlivy dospívání nebo vliv společenské změny, se pokusíme odpovědět s pomocí dvou níže uvedených tabulek 5 a 6 , které uvádí průměrnou hodnotu indexů v každé ze zvolených věkových skupin a ve srovnání let 1991 a 2008.

Tabulka 5: Průměrná hodnota indexu „tolerance" dle věkových kohor†

\begin{tabular}{|l|c|c|c|c|c|}
\hline & $26-30$ & $43-47$ & $60-64$ & $77-81$ & $\begin{array}{c}\text { Rozdíl junioři } \\
\text { vs. senioři }\end{array}$ \\
\hline 1991 & 5,2 & 4,8 & 4,2 & 3,2 & 2 \\
\hline 2008 & 6,1 & 5,5 & 4,6 & 3,8 & 2,3 \\
\hline Rozdíl 2008-1991 & 0,9 & 0,7 & 0,4 & 0,6 & - \\
\hline
\end{tabular}

Poznámka: Jedná se o index přepočítaný pouze pro položky dostupné pro oba sledované časové body. 
Tabulka 6: Prưměrná hodnota indexu „občanská morálka“ dle věkových kohort

\begin{tabular}{|l|c|c|c|c|c|}
\hline & $26-30$ & $43-47$ & $60-64$ & $77-81$ & $\begin{array}{c}\text { Rozdíl junioři } \\
\text { vs. senioři }\end{array}$ \\
\hline 1991 & 2,5 & 2,1 & 1,8 & 1,6 & 0,9 \\
\hline 2008 & 3,5 & 2,8 & 2,3 & 1,9 & 1,6 \\
\hline Rozdíl 2008-1991 & 1,0 & 0,7 & 0,5 & 0,3 & - \\
\hline
\end{tabular}

Poznámka: Jedná se o index přepočítaný pouze pro položky dostupné pro oba sledované časové body.

V př́ípadě občanské morálky se zdá, že stárnutí vede k vyšší otevřenosti v hodnocení akceptability sledovaného chování, nebot' v čase T1 byli junioři, dospělí i senioři konzervativnější (měli nižší skóre) než v čase T2. Junioři „vyzrávají“ k liberálnosti i v případě tolerance k otázkám, jako je homosexualita, potrat, rozvod. Dospělí a senioři ale reagují v této dimenzi morálky opačně, za sedmnáct let dospěli $\mathrm{k}$ větší striktnosti a v roce 2008 mají v těchto otázkách skóre nižší než na počátku v roce 1991, kdy jim bylo čtyřicet tři, respektive šedesát let. Mezigenerační změny ale s postupem času slábnou, protože rozdíly mezi juniory jsou meziročně vyšší než změny mezi (nejstaršími) seniory. Osmdesátníci roku 1991 a roku 2008 jsou si podobnější ve svých postojích než junioři.

Jiný způsob hodnocení trendů zvolili Abramson a Inglehart (1992), kteří srovnávali rozdíly procentních bodů mezi krajními kategoriemi. Také my jsme kardinální hodnoty indexů kolapsovali do tří kategorií podle kvartilů s nejpočetnějším středem a vypočítali jsme prostý matematický rozdíl mezi podíly v kategorii nejvíce a nejméně tolerantních. Po aplikaci této metody na naše výsledky jsme získali tabulky 7 a 8 .

Tabulka 7: Rozdíl v podílech konzervativnějších a liberálnějších osob v otázkách „tolerance“ (index) dle věkové kohorty (procentní body)

\begin{tabular}{|l|c|c|}
\hline & 1991 & 2008 \\
\hline $26-30$ & -7 & -25 \\
\hline $43-47$ & 6 & -12 \\
\hline $60-64$ & 27 & 11 \\
\hline $77-81$ & 55 & 42 \\
\hline
\end{tabular}

Poznámka: Jedná se o index přepočítaný pouze pro položky dostupné pro oba sledované časové body.

Tabulka 8: Rozdíl v podílech konzervativnějších a liberálnějších osob v otázkách "občanské morálky" (index) dle věkové kohorty (procentní body)

\begin{tabular}{|l|c|c|}
\hline & 1991 & 2008 \\
\hline $26-30$ & -9 & -34 \\
\hline $43-47$ & 7 & -20 \\
\hline $60-64$ & 34 & 8 \\
\hline $77-81$ & 48 & 32 \\
\hline
\end{tabular}

Poznámka: Jedná se o index přepočítaný pouze pro položky dostupné pro oba sledované časové body. 
Výsledky získané touto metodou výpočtu jsou $\mathrm{v}$ zásadě podobné výsledkům dosaženým výše. Napríílad v tabulce 7 můžeme vidět, že zatímco lidé narození $v$ šedesátých letech 20. století posilují svoji liberalitu, zejména u lidí narozených ve třicátých letech se konzervativní postoje ještě rozhojnily (rozdíl 27 procentních bodů $\mathrm{v}$ T1 a 42 procentních bodů v T2). Můžeme proto hovořit o kombinovaných vlivech jak inter-, tak intra- generačních změn. V některých oblastech stárnutí nemění morální klima společnosti, ale v jiných stárnutí působí ve stejném směru jako generační následnost. Jako to $\mathrm{v}$ podobných souvislostech uzavírá Hellevik (2002: 302), „,nelze vydat obecný závěr k tomu, zda věkové rozdíly v hodnotové orientaci odráží efekty kohortní nebo životního cyklu“.

Rozdílnou generační/kohortní dynamiku sledovaných dimenzí můžeme snad vysvětlit i jejich odlišným obsahem. V př́padě „tolerance“ by svoji roli mohl hrát faktor zkušenosti: junioři relativizují svi̊j postoj tváŕí v tvář situacím, se kterými se intenzivně setkávají (teprve) jako lidé v určitém bodě životního cyklu (dospělí), v určitém, specifickém, kulturně-historickém kontextu, který jejich postoj spoluurčuje. Přesto se síla společenských změn nezdá překrývat významy vložené (ranou) socializací. Některé události se sice stávají obvyklejší, nikoliv ovšem nutně „,normální“.

\section{Vliv religiozity}

Již několikrát jsme uvedli vliv religiozity respondenta na jeho postoje, a proto se v následujícím oddíle zaměříme na tyto možné souvislosti detailněji. Religiozita přitom sama o sobě není čistou „nezávislou“ proměnou. V níže uvedeném grafu 3 podíly osob hlásících se $\mathrm{k}$ některé $\mathrm{z}$ církví vykazují zřetelnou souvislost $\mathrm{s}$ věkem respondenta. Velmi podobný, i když ne zcela identický obrázek bychom získali i v př́padě, že bychom sledovali EVS proměnné, jako je například víra $\mathrm{v}$ Boha. $\mathrm{V}$ dalším textu proto osoby religiózní někdy také zkratkovitě označujeme jako věřící a osoby $\mathrm{k}$ církvi či náboženství se nehlásící jako nevěrící. Organizovaná religiozita/víra v Boha je na základě těchto výsledků doménou starších osob.

Graf 3: Podíl respondentů hlásících se k nějaké církvi nebo náboženství dle věkových kategorií

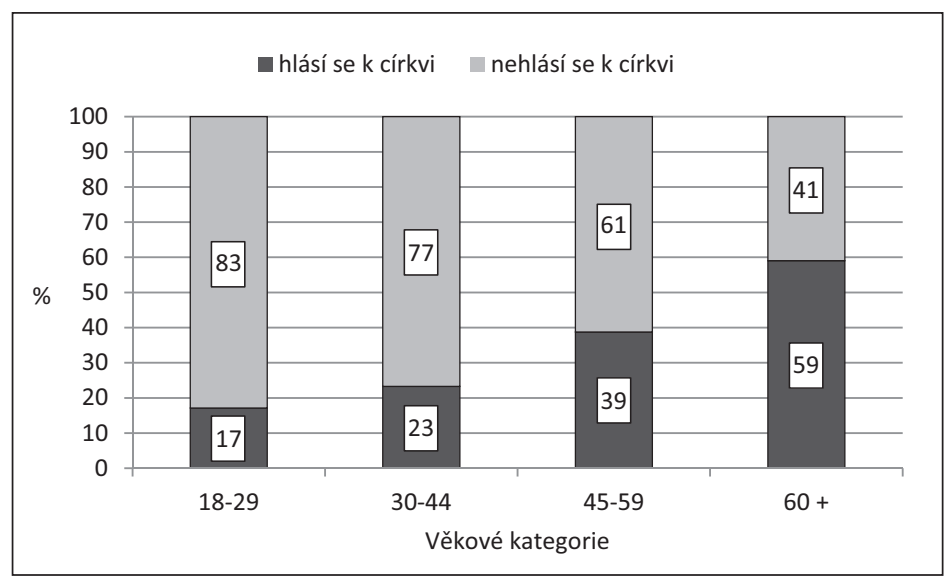


Protože většina již dřive citovaných autorů hovoří o variabilitě intenzity morálních postojů $\mathrm{v}$ prímé souvislosti $\mathrm{s}$ individualizací, konzumerismem, hédonismem a zejména se sekularizací evropských společností, pozastavili jsme se nad otázkou, jakou roli hraje $\mathrm{v}$ těchto postojích religiozita právě $\mathrm{v}$ kombinaci s věkem respondenta a $\mathrm{v}$ kontextu strukturálních změn silně sekularizované (Lužný a Nešpor 2009, Vido 2008), a přitom populačně stárnoucí české společnosti.

Z tabulky 3 již víme, že organizovaná religiozita snižuje toleranci ke všem třem sledovaným formám „nemorálního“ jednání. Je tedy nasnadě se podívat, jakým způsobem religiozita ovlivňuje vztah mezi věkem a seniorskou konzervativností. Nejdřive jsme využili testu párové a dílčí korelace mezi jednotkami věku respondenta a třemi indexy. Indexy tolerance a občanské morálky ukazovaly pouze střední závislost $(\mathrm{r}=-0,18$, respektive $-0,24)$, ale při testu na vliv organizované religiozity se oba korelační koeficienty zvýšily $(r=-0,25$, respektive -0,32). Nepatrně se při testu vlivu religiozity zvýšila i souvislost mezi věkem a indexem moderních rizik, která byla původně velice nízká $(\mathrm{r}=-0,09$, respektive $-0,12)$.

Graf 4: Prưměry indexů podle věkových skupin respondentů a jejich religiozity (2008)

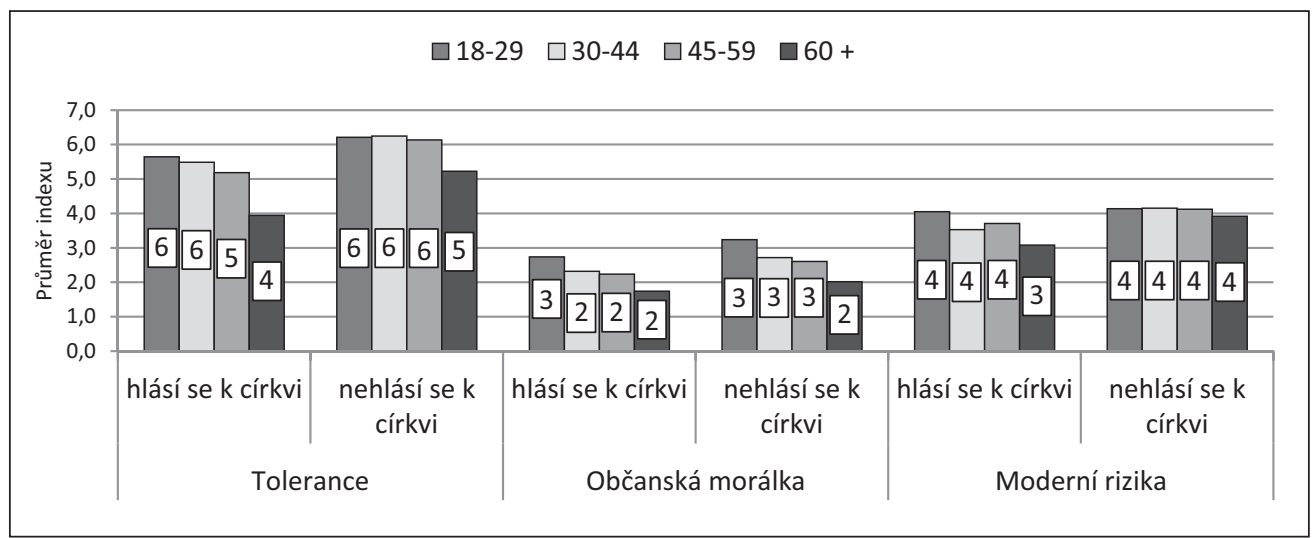

$\mathrm{V}$ prrípadě moderních rizik a tolerance mají věřící respondenti ve svých postojích větší rozptyl než respondenti nevěřící. V oblasti tolerance se zároveň zdá, že organizovaná religiozita hraje $\mathrm{v}$ př́padě seniorů větší úlohu při definování síly postoje, než je tomu u ostatních věkových skupin (věřící senioři mají hodnotu indexu 3,9 bodů, kdežto senioři-ateisté 5,2 body; viz graf 4). Odhlédneme-li od faktu, že je oblast občanské morálky obecně nejpř́ísněji hodnocená, je do jisté míry paradoxem, že je tato oblast, nejexplicitněji navázaná na starozákonní desatero, nejméně ovlivněna religiózností respondenta. Může se ale jednat i o tzv. efekt stropu, tj. že rozptyl celé populace je natolik blízko hraniční hodnotě úplného odsouzení, že větší variabilita není ani možná. 
Tabulka 9: Index tolerance (k rozvodům, homosexualitě a potratu)

\begin{tabular}{|c|c|c|c|c|c|c|c|}
\hline \multicolumn{4}{|c|}{1991} & \multicolumn{4}{|c|}{2008} \\
\hline věk & $\begin{array}{l}\text { hlásí se } \\
\text { k církvi }\end{array}$ & $\begin{array}{l}\text { nehlásí se } \\
\text { k církvi }\end{array}$ & $\begin{array}{l}\text { rozdíl mezi } \\
\text { ne/věřícími }\end{array}$ & věk & $\begin{array}{l}\text { hlásí se } \\
\text { k církvi }\end{array}$ & $\begin{array}{l}\text { nehlásí se } \\
\text { k církvi }\end{array}$ & $\begin{array}{l}\text { rozdíl mezi } \\
\text { ne/věrícími }\end{array}$ \\
\hline 77-81 & 3,1 & 3,6 & 0,5 & 77-81 & 3,2 & 4,6 & 1,4 \\
\hline $60-64$ & 3,9 & 4,6 & 0,7 & $60-64$ & 4,2 & 5,1 & 0,9 \\
\hline $43-47$ & 4,2 & 5,2 & 1,1 & $43-47$ & 4,3 & 5,8 & 1,6 \\
\hline $26-30$ & 3,9 & 5,5 & 1,6 & $26-30$ & 4,9 & 6,2 & 1,4 \\
\hline $\begin{array}{l}\text { rozdíl } \\
26-30 / \\
77-81\end{array}$ & 0,8 & 1,9 & - & $\begin{array}{c}\text { rozdíl } \\
26-30 / \\
77-81\end{array}$ & 1,7 & 1,7 & - \\
\hline
\end{tabular}

Poznámka: Hodnoty v tabulce jsou počítány pouze z položek, které jsou k dispozici pro oba sledované roky. Hodnoty jsou zaokrouhleny.

Tabulka 10: Index ospravedlnění porušení občanské morálky (zneužití podpory, šizení na daních, Ihaní a úplatkářství)

\begin{tabular}{|l|c|c|c|c|c|c|c|}
\hline \multicolumn{4}{|c|}{1991} & \multicolumn{4}{c|}{2008} \\
\hline věk & $\begin{array}{c}\text { hlásí se } \\
\text { k církvi }\end{array}$ & $\begin{array}{c}\text { nehlásí se } \\
\text { k církvi }\end{array}$ & $\begin{array}{c}\text { rozdíl mezi } \\
\text { ne/věřícími }\end{array}$ & věk & $\begin{array}{c}\text { hlásí se } \\
\text { k církvi }\end{array}$ & $\begin{array}{c}\text { nehlásí se } \\
\text { k církvi }\end{array}$ & $\begin{array}{c}\text { rozdíl mezi } \\
\text { ne/věř́cími }\end{array}$ \\
\hline $77-81$ & 1,5 & 1,9 & 0,4 & $77-81$ & 1,8 & 1,7 & $-0,1$ \\
\hline $60-64$ & 1,8 & 1,9 & 0,1 & $60-64$ & 2,0 & 2,5 & 0,5 \\
\hline $43-47$ & 1,9 & 2,3 & 0,4 & $43-47$ & 2,4 & 2,9 & 0,5 \\
\hline $26-30$ & 2,4 & 2,5 & 0,0 & $26-30$ & 2,5 & 3,5 & 1,0 \\
\hline $\begin{array}{l}\text { Rozdíl } \\
26-30 / \\
77-81\end{array}$ & 1,0 & 0,6 & - & $\begin{array}{c}\text { Rozdíl } \\
26-30 /\end{array}$ & 0,7 & 1,9 & - \\
\hline
\end{tabular}

Poznámka: Hodnoty v tabulce jsou počítány pouze z položek, které jsou k dispozici pro oba sledované roky. Hodnoty jsou zaokrouhleny.

Předcházející dvě tabulky reflektují možné posuny mezi kohortami a v čase. S vědomím omezené výpovědní schopnosti této analýzy, kterou jsme diskutovali již výše, můžeme na základě tabulky 9 říci, že zatímco nereligiózní respondenti s tím, jak stárnou, své postoje spíše udržují na stejné hladině, věřící junioři se liberalizují a věřící senioři naopak inklinují $\mathrm{k}$ odmítavějšímu postoji. $\mathrm{V}$ případě ospravedlnění občanské morálky jsou to naopak religiózní respondenti, kteří s tím, jak stárnou, své postoje př́iliš nemění.

Přestože tedy senioři patří významně častěji ke skupinám hlásícím se k organizovaným církvím a náboženstvím, není religiozita činitelem, který by rozhodujícím způsobem determinoval jejich konzervatismus. Ve většině jsou konzervativnější bez ohledu na svoji víru. Jedinou výjimkou, kde se zdá víra zpř́sňovat pohled na problematiku, je oblast tzv. moderních rizik, tedy napríklad genetické manipulace potravin nebo experimentů na lidských embryích. 


\section{Generační/kohortní morálka v Evropském kontextu}

Halman (1995), který si položil otázku, zda dochází k poklesu morálky v Evropě již na základě dat EVS z let 1981 a 1990, mimo jiné ukázal, že morálka je do značné míry kulturně specifická a že vliv kultury, zde reprezentované národním státem, je silnější, než např́ílad vliv vzdělání a věku. Aniž bychom $\mathrm{v}$ tomto textu směřovali $\mathrm{k}$ přímé replikaci Halmanova zkoumání na aktuálních datech, využili jsme některé $\mathrm{z}$ jeho postupů $\mathrm{k}$ ilustraci pozice české populace a jejích morálních hodnot v evropském kontextu. Jak jsme již uvedli, Halman pracoval pouze s tzv. občanskou morálkou a tolerancí. Pomocí faktorové analýzy jsme tyto dvě dimenze extrahovali z evropského souboru EVS z roku 2008 i my. ${ }^{11}$ Základní výsledky shrnuje tabulka 11.

Tabulka 11: Průměrné hodnoty indexů „tolerance“ a „občanská morálka“ dle věkových kategorií $\checkmark$ Evropě a $\vee$ ČR

\begin{tabular}{|c|c|c|c|c|c|c|c|c|c|}
\hline \multirow{3}{*}{ Věk } & \multicolumn{4}{|c|}{ Evropa } & \multirow{3}{*}{ Věk } & \multicolumn{4}{|c|}{ Česká republika } \\
\hline & \multicolumn{2}{|c|}{ Tolerance } & \multicolumn{2}{|c|}{ Občanská morálka } & & \multicolumn{2}{|c|}{ Tolerance } & \multicolumn{2}{|c|}{ Občanská morálka } \\
\hline & Průmèr & $\begin{array}{c}\text { Směr. } \\
\text { odchylka }\end{array}$ & Průměr & $\begin{array}{c}\text { Směr. } \\
\text { odchylka }\end{array}$ & & Průmèr & $\begin{array}{c}\text { Směr. } \\
\text { odchylka }\end{array}$ & Průměr & $\begin{array}{c}\text { Směr. } \\
\text { odchylka }\end{array}$ \\
\hline $18-24$ & 4,68 & 2,41 & 2,82 & 1,68 & $18-24$ & 6,01 & 2,50 & 3,50 & 1,94 \\
\hline $25-30$ & 4,93 & 2,50 & 2,71 & 1,69 & $25-30$ & 6,11 & 2,31 & 3,37 & 1,85 \\
\hline $31-45$ & 4,90 & 2,46 & 2,51 & 1,59 & $31-45$ & 5,93 & 2,24 & 2,76 & 1,55 \\
\hline $46-60$ & 4,66 & 2,42 & 2,32 & 1,54 & $46-60$ & 5,70 & 2,25 & 2,84 & 1,62 \\
\hline $61-70$ & 4,38 & 2,32 & 2,15 & 1,55 & $61-70$ & 4,60 & 2,31 & 2,15 & 1,21 \\
\hline $70+$ & 3,96 & 2,22 & 1,99 & 1,52 & $70+$ & 4,36 & 2,26 & 1,93 & 1,07 \\
\hline Celkem & 4,66 & 2,43 & 2,43 & 1,61 & Celkem & 5,57 & 2,37 & 2,77 & 1,64 \\
\hline
\end{tabular}

Poznámka: Škála ospravedlnitelnosti: 1 = nikdy, 10 = vždy. Celoevropský průměr je včetně ČR.

Obecně liberálnější status ČR konstatovaný již v tabulce 2 se potvrzuje i v detailnější tabulce 11 a platí pro všechny věkové kategorie respondentů.

11 Pro tuto faktorovou analýzu jsme využili metodu Principal Component Analysis s rotací Varimax. KMO test dosáhl hodnoty 0,924 . Ve dvou extrahovaných faktorech je vysvětleno 57,4\% rozptylu. Zahrnuty byly pouze položky s faktorovou zátěží vyšší než 0,4 . Faktor „občanské morálky“ zahrnoval devět položek (přijmout úplatek, ujet z legrace s autem, šidit na daních, lhát, neplatit jízdné v MHD, pobírat neoprávněně dávky, brát lehké drogy, jako ženatý/vdaná mít poměr, platit hotově bez vystavení účtu), faktor ,tolerance“ zahrnoval pět položek (rozvod, potrat, euthanasie, homosexualita, umělé oplodnění). Halman (1995) ve svém článku přesné obsahy a formu extrakce svých faktorů neuvádí, ale z jeho textu je zřejmé, že se jeho i naše položky dotýkají stejných oblastí. Přesto je tento nedostatek informací jedním z důvodů, proč upouštíme od přímého srovnávání s tímto starším Halmanovým výzkumem. 
Pokud k sobě vztáhneme obě morální dimenze, tak jak to dělá graf 5 níže, získáme čtyři kategorie morálních profilů jednotlivých zemí. První kategorie vykazuje vysoké skóre v obou sledovaných dimenzích, a patří tak k těm nejliberálnějším. Kromě Dánska, Francie, Belgie a Holandska, typických lídrů hodnotové relativity, v tomto kvadrantu nacházíme i země bývalého „východního“ bloku, včetně Česka a Slovenska. Druhou velkou kategorii zemí tvoří seskupení v levém spodním kvadrantu, tedy země s nízkým skóre jak v oblasti tolerance, tak v oblasti občanské morálky. Zařadily se sem státy silně definované tradiční kulturou, tj. zejména státy bývalé Jugoslávie a bývalého Sovětského svazu (Kosovo, Makedonie, Srbsko, Arménie, Gruzie, Ukrajina...). Třetí kategorii zemí s relativně vyšší liberalitou v oblasti občanské morálky, ovšem striktnější v otázkách homosexuality, potratů a rozvodů, tvoří nábožensky založené státy - např́iklad Albánie, Polsko, Rumunsko, Rusko, hraničně také Irsko. Protipólem je levý horní kvadrant grafu 5 s relativně vysokou mírou tolerance, ale striktnější v oblasti občanské morálky, což je charakteristika zemí, jako je např́klad Mad'arsko, Bulharsko, Portugalsko, Finsko. Na pomyslné hranici oddělující obecně liberálnější postoje pak leží Německo ${ }^{12}$ a Slovinsko. Podobně jako Halman tedy zjišstujeme, že bývalý ,,východní blok“ není uniformní masou a rozdíly v míře organizované religiozity nemohou vysvětlit všechny mezikulturní rozdíly (například mezi Českem a Slovenskem, kde jsou podíly subjektivně religiózních osob $32 \%$ vs. 81 \%).

Graf 5: Občanská morálka a tolerance (prưměry indexů)

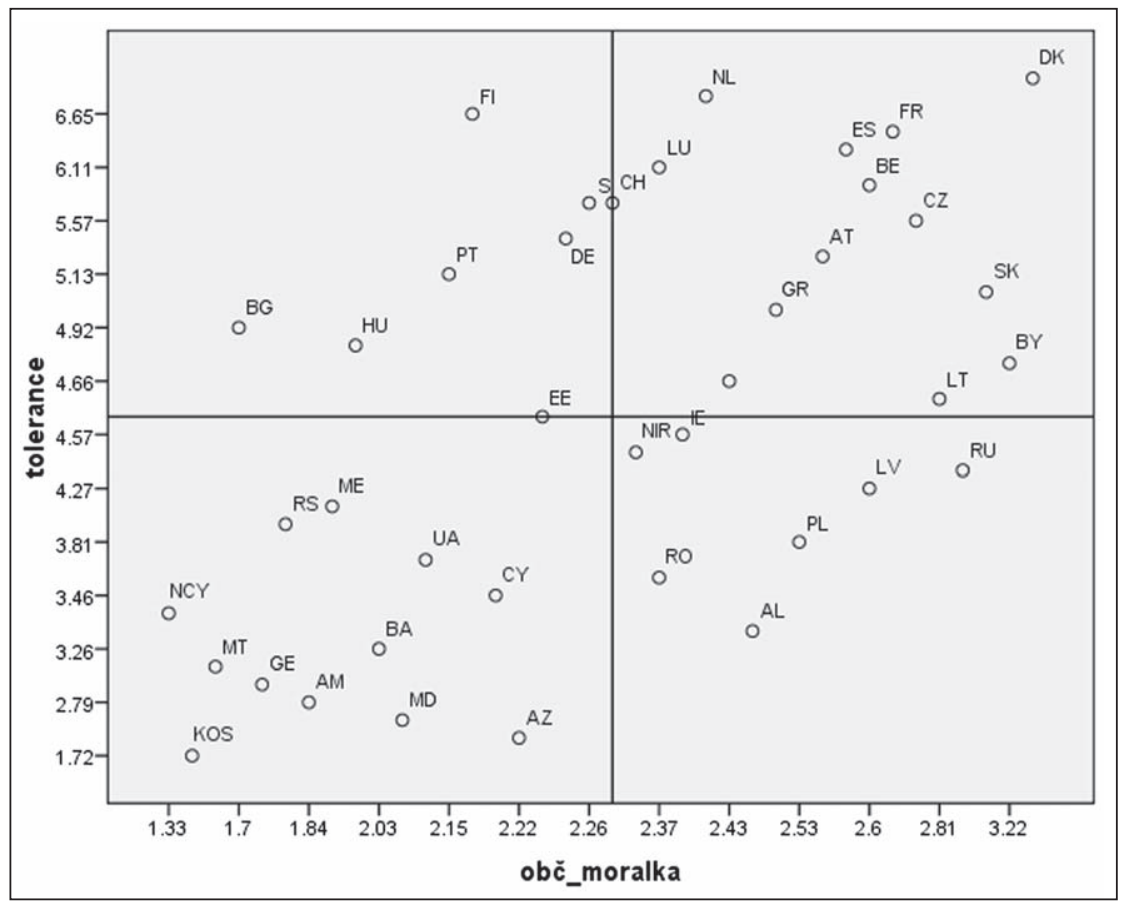

12 Německo „táhne“ do levé oblasti grafu jeho východní část. 
Vrat’me se ale k našemu primárnímu zájmu, a tím jsou rozdíly věkové. Abychom mohli rozhodnout o výhradní platnosti hypotézy o působení kalendářního času anebo hypotézy o kohortních efektech, měli bychom být schopni demonstrovat jejich platnost $\mathrm{v}$ různých kontextech. Zvláště to platí u charakteristik stáŕí, které jsou nezř́́dka prezentovány jako biologicky podmíněné, a tudíž kulturně téměř univerzální. Je tedy tendence ke konzervatismu obecnou zkušeností provázející stárnutí? Pro odpověd' na tuto otázku opět alternujeme Halmanův (1995) př́stup a v grafu 6 porovnáváme průměrné hodnoty indexu tolerance pro šest věkových skupin ve vybraných zemích evropského souboru EVS. ${ }^{13}$

Graf 6: Index „,olerance“ dle šesti věkových skupin (prưměr součtového indexu)

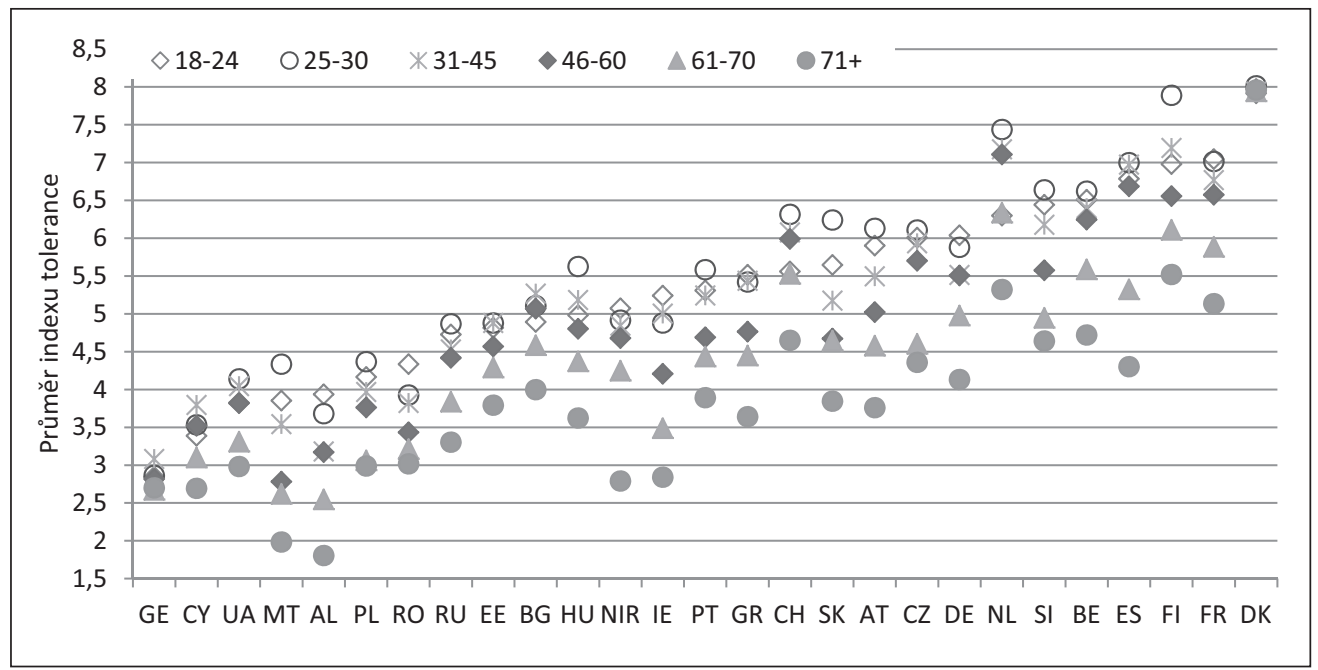

Poznámka: $\vee$ grafu prezentujeme pouze ad hoc výběr ze zúčastněných zemí. Data jsou pro rok 2008, respektive 2009 pro Belgii a Finsko. Země jsou v grafu řazeny od nejmenší hodnoty pro věkovou skupinu 18-24 let.

I když graf 6 znovu potvrzuje tezi závislosti míry liberality na věku respondenta, zároveň velice ilustrativně potvrzuje Halmanovo (1995) obecné zjištění, že rozdíly mezi zeměmi jsou větší než mezi jednotlivými věkovými skupinami. Věk totiž působí na míru liberality $\mathrm{v}$ různých kulturách různě. Na jedné straně máme př́klad Rumunska, kde míra tolerance klesá se zvyšujícím se věkem v přibližně stejných intervalech mezi jednotlivými věkovými

13 Halman (1995) pracoval pouze se čtyřmi věkovými kategoriemi. My jsme pro lepší ilustraci rozdělili obě krajní kategorie (18-30 a 61+), abychom získali podrobnější obrázek. Vycházeli jsme z předpokladu, že nejmladší věková skupina bývá považována za nositele nových hodnot v důsledku silného působení masových médií (Halman 1995) nebo socializace obecně (Treas 2002). Naše data ale ukazují, že tomu tak nutně není. V př́ípadě rozdělení seniorské kategorie reagujeme na běžně užívaný nešvar (nejen v sociálních vědách) považovat seniory za homogenní skupinu. Troufáme si tvrdit, že při naději na dožití, která v Evropě běžně dosahuje k věku 80 let, je společné hodnocení šedesátníků a osmdesátníků zhruba stejně efektivní jako hodnocení novorozence a dvacetiletého člověka. 
skupinami. Naopak o de facto věkové nezávislosti můžeme mluvit v př́padě Dánska a Gruzie, dvou zemí na opačných koncích toleranční škály. Dalším možným modelem věkové závislosti je Halmanem (1995: 434) identifikovaný model většího rozptylu u nejmladších skupin v kontrastu s menší fragmentací nejstarších skupin, ale v našich datech ho téměř nenacházíme. Naopak obrácený model, tedy vyšší semknutost mladších skupin a větší rozmanitost u seniorů, vykazují např́klad Francie a Irsko. V jiných zemích se ukazuje spíše obecný model „odskoku“ seniorů od ostatní populace, jako je tomu v Polsku a v České republice. Zajímavý je odklon řady zemí od modelu „nejmladší skupina rovná se nejliberálnější postoj“. Pokud sledujeme mladé lidi do 25 let a mladé dospělé do třiceti let odděleně, ve čtrnácti př́ipadech z dvaceti sedmi v grafu prezentovaných jsou lídry tolerance spíše mladí dospělí než pozdní teenageři. Viditelné je to $\mathrm{v}$ prípadě Finska, Mad’arska, Nizozemí, Slovenska a republiky Černá Hora. V př́padě Kypru se jako nejliberálnější profiluje dokonce věková skupina mezi 31 a 45 lety. Naopak představiteli nejkonzervativnějších názorů jsou ve všech sledovaných zemích nejstarší senioři (71+). Ve Švýcarsku a Severním Irsku jsou dokonce tyto krajní seniorské kategorie významně odděleny od zbytku populace.

Graf 7: Index „občanské morálky“ dle šesti věkových skupin (prưměr součłového indexu)

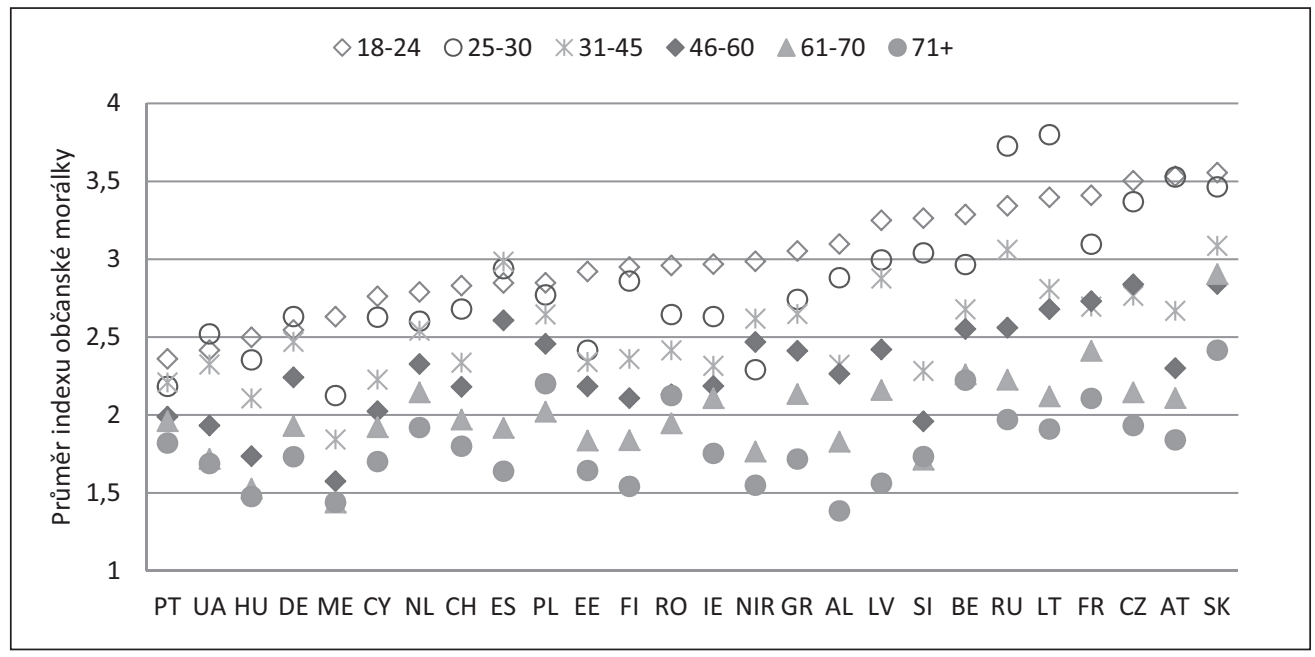

Poznámka: V grafu prezentujeme pouze ad hoc výběr ze zúčastněných zemí. Data jsou pro rok 2008, respektive 2009 pro Belgii a Finsko. Země jsou v grafu řazeny od nejmenší hodnoty pro věkovou skupinu 18-24.

Graf 7 podává obrázek o věkových souvislostech ospravedlnitelnosti jednání, které na základě našich předchozích výsledků - není běžně v souladu s morálkou občanskou. Již na první pohled je zrèejmé, že se v několika bodech liší od grafu předchozího. Zřejmě nejvýraznějším rozdílem je „vedení“ nejmladší věkové skupiny v tendenci k liberalizaci postojů. V př́ípadě zemí, jako je Moldávie nebo Estonsko, si nejmladší věková „teen“ skupina drží zřetelný odstup i od mladých dospělých. Vedoucí pozice starších věkových skupin jsou mnohem méně časté než u „tolerance“, spíše výjimečné př́iklady můžeme najít mezi Španěly, 
Rusy a Litevci (LT). Vzhledem $\mathrm{k}$ tomu, že jsme v grafu 7 zvolili řazení dle hodnoty nejmladších skupin respondentů a ty se seřadily téměř v lineární posloupnosti, je zajímavé sledovat dynamiku dolní pomyslné linie tvořené nejstaršími respondenty. Oproti faktoru „tolerance“ konzervatismus nejstarších seniorů již není tak jednoznačný (viz Mad'arsko nebo Rumunsko) a kolísá také relativní vzdálenost od nejprogresivnější mladé skupiny. Nejstarší senioři se juniorům nejvíce přibližují v Portugalsku a Polsku, rozdíl zde činí pouze asi 0,6 bodu. Naopak v Lotyšsku (LV), Rakousku a Albánii je dělí 1,7 bodů sledované desetibodové škály. ${ }^{14}$ Mimo těchto specifik můžeme i zde vypozorovat všechny modely věkové závislosti popsané u předchozího grafu 6 , tj. různou disperzi u krajních kategorií a jejich různě intenzivní „odskoky“. Můžeme pouze spekulovat, že „odskoky“ jsou formovány odlišnou generační zkušeností. Pro lepši čitelnost grafu 7 v něm neuvádíme extrémní hodnoty Dánska, které vykazuje průměr na škále „občanské morálky“ 7,5 bodu. Oproti všem ostatním zemím se liší i tím, že souvislost $\mathrm{s}$ věkem zde ukazuje na nepřímou úměru. Nejmladší skupina má v průměru hodnotu indexu 7,3 bodu, nejstarší o 0,5 bodu více, tj. 7,8 bodu.

Vzkazem všech tř́ grafů prezentovaných $v$ tomto oddíle, mimo již řečeného, je také relativní nespolehlivost striktního dělení zemí na „moderni““ a „tradiční“. Byli bychom proto skeptičtí k možnostem formulování hypotéz o vzájemném sbližování jednotlivých zemí (kultur) v důsledku globálních dopadů modernizace, individualizace, sekularizace a šírícího se postmaterialismu. Spíše se zdá, že i kdyby tyto procesy působily na všechny kultury rovnoměrně (Abramson a Inglehart 1992), nacházely by se společnosti a v nich žijící generace na různé úrovni „vývoje“, což by mohlo mít za následek identifikovanou variabilitu. Působí zde spíše efekt jezdících schodů (,eskalátoru“), kdy se sice i spodní schody posunují nahoru, ale ty před nimi svoje vedoucí pozice neztrácejí. Ale i tento závěr je potřeba brát s rezervou. Staví totiž na předpokladu lineárního vývoje a ten, jak jsme již několikrát naznačili, v př́padě morálních hodnot není striktním pravidlem. ${ }^{15}$

Variabilita mezi státy není pouze $\mathrm{v}$ jejich kulturních diferencích, ale i v podílu seniorů na jejich populaci. Různé konvergenční scénáře předpokládají do budoucna sbližování např́iklad klesajících měr porodnosti, a tím i populačního stárnutí. Dnes však v Evropě koexistují státy s $11 \%$ populace nad 65 let se státy, kde je tento podíl téměř dvojnásobný (např́klad Německo, zdroj dat Eurostat 2008). V našich výpočtech podíl seniorů nekoreluje s průměry indexu občanské morálky vůbec a s indexem tolerance mírně, a to v překvapivém, pozitivním trendu: čím starší populace, tím vyšší míra ospravedlnitelnosti porušování tradičních rodinných vzorců (viz graf 8). Jestliže je stárnutí populací fenomén, pro který v historii neexistuje precedens, pouze současné vzory (Mullan 2002), pak i z tohoto pohledu stárnutí populace perspektivně nehrozí změnou $\mathrm{v}$ občanské morálce, ale spíše jen mírným př́íklonem $\mathrm{k}$ liberálnějším hodnotám $\mathrm{v}$ oblasti rodiny. I to může být jeden $\mathrm{z}$ argumentů, proč upustit od dikce

14 Rozptyl u faktoru „tolerance“ je přitom ještě o něco větší. Senioři a junioři mají identický názor v Dánsku a Gruzii, o půl bodu se liší v Kosovu a Arménii. Naopak největší rozdíly mezi nimi (2,5 b) jsme zaznamenali ve Španělsku a Irsku.

15 Testování těchto hypotéz by vyžadovalo srovnání ve více časových bodech, které bohužel pro mezinárodní databázi v této chvíli nemáme $\mathrm{k}$ dispozici. 
spojující stárnutí s hrozbou, a přiklonit se k dikci „stárnutí jako jeden z největší výdobytků lidské civilizace“, a tudíž i znaku moderních, pokrokových společností.

Graf 8: Závislost postojů v indexu tolerance na podílu seniorů v populaci

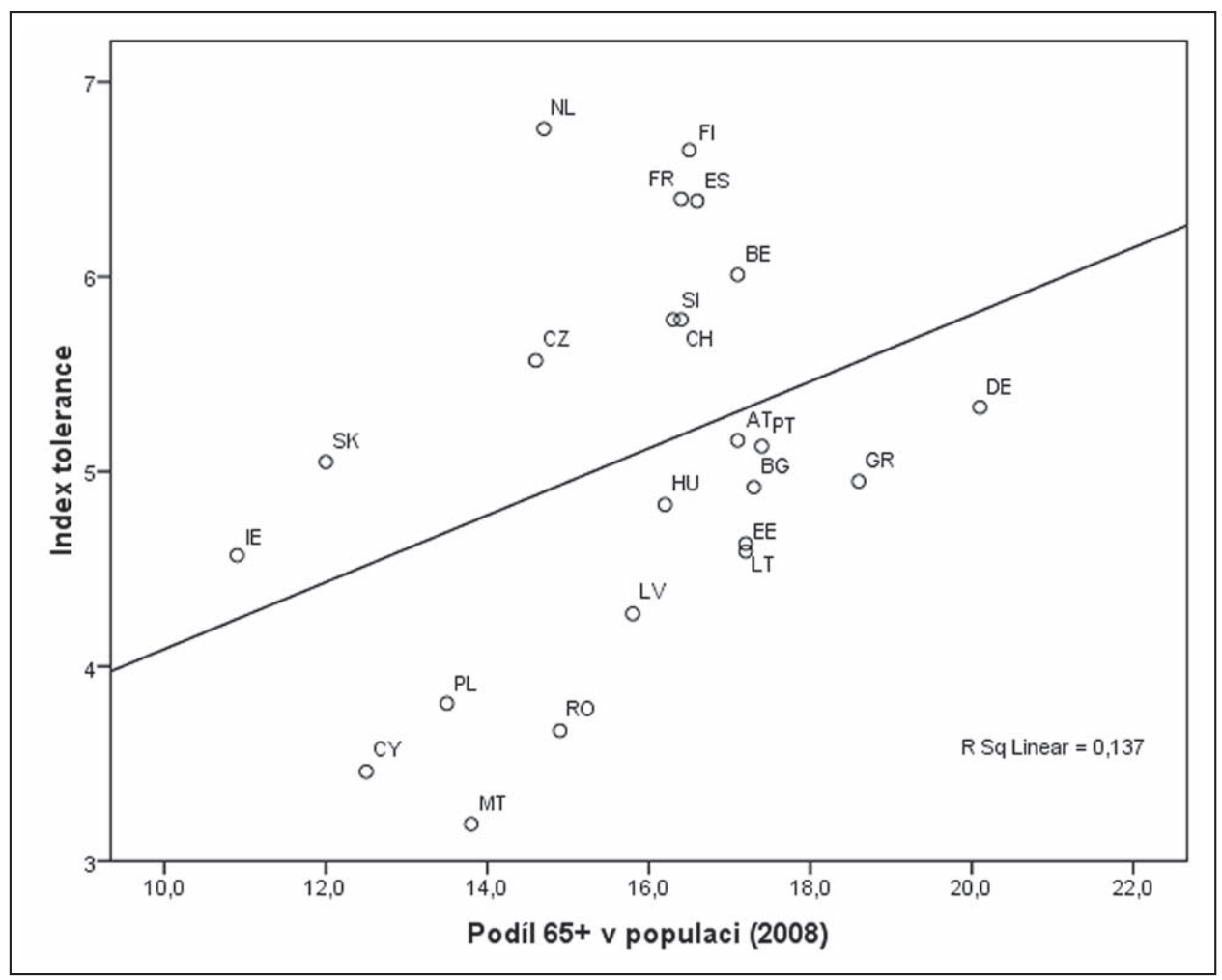

Poznámka: Pouze vybrané státy EU.

Zdroj: Eurostał 2008.

\section{Diskuse a závěry}

Z našich analýz vyplývá, že za posledních sedmnáct let nedošlo $\mathrm{k}$ dramatickému či revolučnímu převratu v morálních hodnotách české společnosti. Posuny, které data Evropského výzkumu hodnot zaznamenaly, lze hodnotit jako relativně malé, a navíc ne nutně lineární. Pokud bychom se spokojili jen s obecným trendem, pak sice můžeme říct, že existuje určitá tendence $\mathrm{k}$ větší liberálnosti, respektive akceptaci plné svobody individuálních voleb a preferencí, ale Češi stále, přinejmenším deklarativně, ctí určité základní hodnoty, jako je nedotknutelnost cizích práv, majetku a manželky. Jak uvádí Dogan (1995), křest’anská morálka se v Evropě stala součástí státu. I to může být jeden z důvodů, že tyto, původně judeo-křest’anské hodnoty zakořenily v naší kultuře a „přežívají“ i v atmosfére posilujícího ateismu (Vidovićová a Suchomelová 2011). 
$\mathrm{Na}$ základě hodnocení rozptylů od průměru pomocí směrodatných odchylek (tabulka 11) se zdá, že starší věkové skupiny ve společnosti sdílejí podobné názory, kdežto mladší lidé jsou ve svých postojích více heterogenní. Ukázali jsme však, že jsou zde významné mezikulturní, ale i mezi-položkové rozdíly. Například Village a Francis (2009) v nedávné studii hodnotili specifickou formu konzervatismu v přístupu $\mathrm{k}$ teologickým postojům a morálním hodnotám příslušníků anglikánské církve. Zjistili, že většina měr konzervatismu u mladších kohort poklesla, nicméně při hlubším sledování různých tradic se ukázalo, že například mladí evangelikálové vykazovali jen malý či dokonce žádný pokles v teologickém či morálním konzervatismu a v př́ípadě biblických postojů byli dokonce konzervativnější než starší respondenti. Změna v postojích není vždy jednosměrná, jak by sousledný model kohortní následnosti implikoval. Postoje vůči rodině, genderu a sexualitě jsou subjektem „sezónních výkyvư“, ovlivňují je „období institucionální afirmace a de-institucionalizace nebo období kolektivního utvrzování následovaná obdobími charakterizovanými snahou o větší individuální svobodu a toleranci““ (Lesthaeghe a Surkyn 1988 in Treas 2002: 270). (Morální) Hodnoty, či možná spíše síla jejich sociálního vynucení jsou často ovlivněny aktuálními událostmi. A to do té míry, že i základ daný v průběhu formativních let může být přizpůsobován nové sociální situaci. Ta je přitom vyjednávána, sociálně konstruována, a konečný ,produkt“ bude spíše odpovídat těm, již se na jeho tvorbě podíleli (sociální elity, zájmové skupiny apod.). Legitimita a schopnost argumentace aktivních tvůrců je pak zásadní pro ustanovení a ustálení morálních hodnot „,nových“. Jako př́klad nám může posloužit vývoj postojů české společnosti vůči homosexualitě. V rámci euforie nově nabyté svobody „pro všechny“ po roce 1989 byla ospravedlnitelnost homosexuality relativně vysoká a stoupala i v dalším roce sledování s tím, jak rostla liberalizace postojů obecně. Rok 2008 (a samozřejmě i roky předchozí) se nesl v poměrně silné veřejné debatě o právech homosexuálů, medializován byl například první český pochod homosexuálů nebo rozsudek Evropského soudu pro lidská práva $\mathrm{v}$ kauze adopce dítěte lesbickou ženou. Debata se proto rozšiřovala za hranice pouhého práva na „coming-out““ a začala zabírat významné otázky práv rodinných, v kterých, jak víme i z našich analýz, je česká společnost relativně rigidní. Regresi v ospravedlnitelnosti homosexuality v roce 2008 by tak bylo možné přičíst i těmto debatám interpretovaným jako útok na rodinný řád. ${ }^{16}$ Podobná dynamika bude pravděpodobně silněji působit i tam, kde ještě není pevně ustáleno, kde/kdo/co je dobro a co zlo. Nemáme zde na mysli přitom pouze absenci legislativní kodifikace, ale i „objektivní“ neznalost v důsledku komplexity problému. Typickým příkladem je položka ,genetická manipulace potravin“, jejíž důsledky nejsou ještě zcela prozkoumány a/nebo veřejnosti známy.

Další z intervenujících bodů je otázka ideového vlivu jednotlivých věkových skupin a generací ve společnosti. V podobných debatách, jako je ta naše, se, bohužel často bez reflexe, hovoří o kultu mládí jako hlavním „nepříteli“ statusu a o významu starších osob (a toho, co představují/reprezentují) ve společnosti. Ideologie věku jako by tu pomáhala odvést

16 Vystihuje to často zaslechnutý výrok typu ,Já proti homosexuálům nic nemám, ale adopce dětí, to už ne!“V datech EVS (2008) s možností homosexuálních a lesbických párů adoptovat děti souhlasilo $32 \%$, z toho pouze $9 \%$ rozhodně. Oproti tomu nesouhlas vyjádřilo $41 \%$, z toho $15 \%$ rozhodně (Rabušic a Hamanová 2009: 174). 
pozornost od skutečných hybatelů, kterými jsou ekonomické a politické elity a zájmové skupiny, často sycené osobami v různém věku. Viděli jsme, že názoroví vůdci, přijmeme-li představu, že vyšší tolerance rovná se pokrok, nejsou nutně př́slušníky nejmladší věkové skupiny a př́slovečná „válka generací“ o morální hodnoty není otázkou krajních skupin věkového kontinua. To ostatně potvrzují i teoretikové, jako napríklad Kalish (1969), kteří vidí generaci nejmladších a nejstarších jako spojence, překonávající generační rozdíly (generation-gap allies). Některé teorie, např́klad původní pojetí ageismu u Butlera (1975), obviňují společnost, že se dostala do situace, kdy je percipovaná distance mezi jednotlivými generacemi takového rozsahu, že znemožňuje mladým lidem identifikovat se se staršími lidmi jako s př́buznými lidskými bytostmi. Již několikrát citované šetření Ageismus 2007 potvrdilo, že s výrokem „Mladí a staři lidé - to jsou dva zcela odlišné světy“ souhlasí $60 \%$ dospělé české populace. Alternativní pohled, že „Staři lidé jsou vlastně stejní jako mladí lidé, jen mají více let" byl tehdy souhlasně ohodnocen jen relativní menšinou (Vidovićová 2008). Netroufáme si tvrdit, že objektivně, ale na základě našich dat a zde prezentovaných analýz z pohledu morálních principů se pravdě přesto více blíží výrok druhý. Populárním obavám z budoucího vývoje společnosti v důsledku jejích demografických změn jasně vévodí zásadní nepochopení mechanismu těchto změn. Zatím se nedaří české veřejnosti vštípit fakt, že senioři roku 2030 se narodili před rokem 1965 a ti z roku 2050 dokonce teprve před rokem 1985. A jak budou stárnout, ponesou si s sebou hodnoty, ve kterých byli socializováni a které zároveň v průběhu svého života (relativně) mírně přizpůsobovali světu kolem sebe. Tyto jejich hodnoty se stejně, jako se (mírně) liší od hodnot jejich rodičů a prarodičů, budou lišit od hodnot jejich dětí a vnuků. Tato druhá část argumentu je dalším vědomostním dluhem, který jako sociální vědci máme vůči české veřejnosti. Až př́liš často se totiž setkáváme $\mathrm{s}$ názorem: „No my jako senioři už přece budeme úplně jiní“; kterému ovšem chybí nutný dodatek, že mladší generace budou ještě ,jinějšsí‘. Možná jsme a budeme technicky / zdravotně / morálně „zdatnější" než naši rodiče, ale zdaleka ne tak jako ti, kteří se narodí v roce 2020 nebo 2040. A možná je i tento princip zachování variability mezi generacemi v pozadí časové neomezenosti povzdechu „O Tempora Cana! O Mores!“ (Ó časy šedé! Ó mravy!).

\section{Literatura}

ABRAMSON, Paul ; INGLEHART, Ronald. Generational Replacement and Value Change in Eight Western European Societies. British Journal of Political Science. 1992, č. 2, roč. 22, s.183 - 228. ISSN 0007-1234.

ATCHLEY, Robert. Social Forces and Aging : An Introduction to Social Gerontology. 9. vyd. Belmont : Wasworth, 1997. 592 s. ISBN 978-0-53-453343-4.

BUTLER, Robert. N. Why Survive? Being Old In America. New York : Harper and Row Publishers, 1975. DANNEFER, Dále ; UHLENBERG, Peter ; FONER, Anne ; ABELES, Ronald P. On the Shoulders of a Giant : The Legacy of Matilda White Riley for Gerontology. Journal of Gerontology : Social Sciences, 2005, č. 6, roč. 60B, s. 296 - 304. ISSN 1758-5368.

DOGAN, Mattei. The decline of religious belief in Western Europe. International Social Science Journal, 1995, č.145, s. $405-418$. ISSN 1468-2451.

EHRENBERGEROVÁ, Lucie ; CICVÁRKOVÁ, Eva. Existuji generačni rozdíly v morálce obyvatel $\check{C} R$ ? Brno : FF Masarykova univerzita, 1995. [Studentská soutěž A.I.Bláhy, rukopis]. 
ERIKSON, Erik H. Životni cyklus rozšírený a dokončený. Praha : Lidové noviny, 1999. 128 s. ISBN 80-7106-291-X.

EUROSTAT. Proportion of population aged 65 and over [online]. 2008. Dostupné z www: http://epp. eurostat.ec.europa.eu/tgm/table.do?tab=table\&init=1\&plugin=1\&language=en\&pcode=tps 00028 .

HALMAN, Loek. Is there a moral decline? A cross-national inquiry into morality in contemporary society. International Social Science Journal, 1995, č. 145, s. 419 - 439. ISSN 1468-2451.

HAVELKOVÁ, Hana ; VODÁKOVÁ, Alena. Heslo Morálka. Velký sociologický slovnik. Praha : Karolinum. 1996. s. 649 - 650. ISBN 80-7184-311-3 (soubor).

HELLEVIK, Ottar. Age differences in value orientation-life cycel of cohort effect? International Journal of Public Opinion Research, 2002, roč. 14, č. 3, s. 286 - 302. ISSN 0954-2892.

INGLEHART, Ronald. Changing values, economic development and political chase. International Social Science Journal, 1995, č. 145. ISSN 1468-2451.

ISAACS, Tracy. Cultural Context and Moral Responsibility. Ethics, 1997, roč. 107, č. 4, s. 670 - 684. ISSN 0014-1704.

KALISH, Richard. The Old and New as Generation Gap Allies. The Gerontologist, 1969, roč. 9, č. 2, s. 83 - 89. ISSN 0016-9013.

KOGAN, Nathan. Personality and aging. In BIRREN J. E. ; SCHAIE W. K.(eds.). Handbook of the psychology of aging. 3. vyd. San Diego : Academic Press, 1990, s. 330 - 346. ISBN 0-12-101263-8.

LESTHAEGHE, Ron; SURKYN, Johan. Cultural Dynamics and Economic Theories of Fertility Change. Population and Development Review, 1988, č. 14, s. 1 - 45. ISSN 1728-4457.

LUŽNÝ, Dušan ; NEŠPOR, Zdeněk R. Náboženství v menšině. 1. vyd. Praha : Malvern, 2009. 206 s. ISBN 978-80-86702-53-7.

McDONALD, Lorraine, STUART-HAMILTON, Ian. Older and More Moral?-Age related Changes in Performance on Piagetian Moral Reasoning Tasks. Age and Ageing, 1996, č. 25, s. $402-404$. ISSN 0002-0729.

MOODY-ADAMS, Michele. Culture, Responsibility, and Affected Ignorance. Ethics, 1994. č. 104, s. 291 - 309. ISSN 0014-1704.

MULlAN, Paul. The Imaginary Time Bomb. Why an Ageing Population is Not a Social Problem. London : I. B. Tauris, 2002. 254 s. ISBN 1-86064-778-2.

PIAGET, Jean. The moral judgement of the child. Harmondsworth, Mddx : Penguin Books edition, 1983.

RABUŠIC, Ladislav; HAMANOVÁ, Jana. Hodnoty a postoje v ČR 1991-2008. (Pramenná publikace European Value Study). Brno : Masarykova univerzita, 2009. 324 s. ISBN 978-80-210-4952-9.

REEVES, Richard. Otázka charakteru. Bulletin OI č. 219. Praha : Občanský institut, 2009.

RILEY, Matylda W. On the Significance of Age in Sociology. American Sociological Review, 1987, roč. 52, č. 1 , s. 1 - 14. ISSN 0003-1224.

SCOTT, Jacqueline. Changing Attitudes to Sexual Morality : A Cross-National Comparison. Sociology, 1998, č. 32, s. 815 - 845. ISSN 0038-0385.

SOROKIN, Pitrim A. Social and Cultural Dynamics : Basic Problems, Principles, and Methods. New York : American Book Company, 1941.

SÝKOROVÁ, Dana. Autonomie ve stárí. Kapitoly z gerontosociologie. Praha : Sociologické nakladatelství, 2007. 285 s. ISBN 978-80-86429-62-5.

STUART-HAMILTON, Ian. Psychologie stárnutí. 1. vyd. Praha : Portál, 1999. 320 s. ISBN 80-7178-274-2.

TREAS, Judit. How Cohorts, education, and Ideology shaped a New Sexual Revolution on American Attitudes toward Nonmarital Sex, 1972-1998. Sociological Perspectives, 2002, roč. 43, č. 3, s. 267 - 283. ISSN 0731-1214.

VIDO, Roman. Křest'anství v hodnotové orientaci současné české společnosti. In Brněnská diecéze 1777-2007 : historie a současnost. Brno : Studio Arx, 2008, s. 166 - 171. ISBN 978-80-86665-04-7. 
VIDOVIĆOVÁ, Lucie. Podléhá česká veřejnost panice z demografie? In KOCOURKOVÁ, J., RABUŠIC, L. (eds.) Sňatek a rodina : zájem soukromý nebo veřejný? Proměny reprodukčního chováni a možností rodinné politiky z hlediska postoju české veřejnosti. 1. vyd. Praha : Katedra demografie a geodemografie, Př́rodovědecké fakulty Univerzity Karlovy v Praze, 2006, s. 82 - 94. ISBN 80-86561-93-3.

VIDOVIĆOVÁ, Lucie. Stárnutí, věk a diskriminace-nové souvislosti. 1. vyd. Brno : MPU, 2008. $233 \mathrm{~s}$. ISBN 978-80-210-4627-6.

VIDOVIĆOVÁ, Lucie ; GREGOROVÁ, Eva. My jsme si stáři nezavinili, to čeká každýho... Povaha a prevence diskriminace seniorů $v \check{C} R$. 1. vyd. Praha : Život 90, 2008. 91 s. ISBN 978-80-254-3808-4.

VIDOVIĆOVÁ, Lucie ; SUCHOMELOVÁ, Věra. Religiozita a spiritualita českých seniorů. Sociologický časopis, 2011. [v tisku].

VILLAGE, Andrew ; FRANCIS, Leslie. An Anatomy of Change : Profiling Cohort Difference in Beliefs and Attitudes among Anglicans in England. Journal of Anglican Studies, 2009, roč. 8, č. 1, s. 59 - 81. ISSN 1740-3553.

\section{Autorka}

je socioložka s dlouhodobým zájmem o problematiku věku, stárnutí a populační změny ve společnosti. Ve svých výzkumech sleduje, jak tyto fenomény ovlivňují společnost, její hodnoty, politiky, ale např́klad i fyzický a symbolický prostor. V roce 2008 publikovala úspěšnou monografii „Stárnutí, věk a diskriminace - nové souvislosti“. V současné době se věnuje problematice stárnutí ve městě a provozuje web http://starnuti.fss.muni.cz.

Kontakt: vidovicova@fss.muni.cz. 